CrossMark \&lick for updates

Cite this: Food Funct., 2015, 6, 1053

\title{
Roles of proanthocyanidin rich extracts in obesity
}

\author{
M. Josepa Salvadó,* Ester Casanova, Anabel Fernández-Iglesias, Lluis Arola and \\ Cinta Bladé
}

\begin{abstract}
Obesity is a multifactorial disorder involving an abnormal or excessive amount of body fat. Obese people have a very high probability of developing metabolic syndrome, a condition in which cholesterol, lipid, and glucose levels rise, causing diabetes and heart disease. From the point of view of energy balance, the main contributors to obesity are excessive energy intake, inadequate energy expenditure and metabolic malfunctions. For this reason, health organisations are working to implement policies and plans to promote healthy eating and active living. However, these measures have not yet proven sufficient to combat this worldwide epidemic; therefore, drugs and bioactive compounds are being investigated to complement the existing strategies. In the present review, we discuss the available data regarding the modulation of obesity by proanthocyanidin rich extracts. Because studies with human subjects are very scarce, we focus on studies using laboratory animals. The results of in vitro studies are included because, although they cannot be directly extrapolated to the biological effects of proanthocyanidin, they can reveal some mechanisms of action.
\end{abstract}

Received 13th November 2014, Accepted 22nd January 2015

DOI: $10.1039 / \mathrm{c} 4 \mathrm{fo} 01035 \mathrm{c}$ www.rsc.org/foodfunction
2013. The prevalence of excessive weight and obesity has also increased in children and adolescents in developing countries, from $8.1 \%$ to $12.9 \%$ in 2013 for boys and from $8.4 \%$ to $13.4 \%$ in girls. ${ }^{4}$ The causes of this chronic disease involve genetic, behavioural and environmental interactions. The major extrinsic contributing factors to the increase of obesity are the increased fat intake and energy density of the diet, together with lower physical activity levels. ${ }^{5}$ Dietary fat is stored very efficiently as body fat but is not efficient in stimulating satiety. ${ }^{6}$ In addition, an increase in fat intake does not stimulate fat oxidation to the same extent carbohydrate and protein oxidation uptake stimulate their own oxidation. ${ }^{7}$ Thus, the limited ability to increase fat oxidation in proportion to fat intake may translate into a positive fat balance and, consequently, to weight gain over time. ${ }^{7-9}$ Furthermore, a blunted substrate switching from lowto high-fat oxidation has been shown in obese, pre-obese and post-obese individuals, and this metabolic inflexibility may be a genetically determined trait. ${ }^{10}$ The decreased fat oxidation can lead to a positive energy balance under conditions of highfat feeding, due to depletion of glycogen stores, which stimulates appetite and energy intake through glucostatic and glucogenostatic mechanisms. ${ }^{10}$ Obesity has also been associated with hyperinsulinaemia as a result of insulin resistance and can be associated with reduced fat oxidation and metabolic inflexibility. ${ }^{11}$ The primary method used to combat obesity is a combination of diet and exercise to balance the energy equation; however, this solution does not seem to work for many people who are unable to maintain the desired body weight with lifestyle changes alone. Thus, several anti-obesity 
drugs have been commercialised, but their usage has been associated with adverse side-effects. In the last few decades, researchers have turned their attention towards food, particularly from the plant and marine worlds, in search of ingredients that improve obesity and its associated diseases. Some food and food components have been shown to affect appetite regulation, fat oxidation, energy uptake or thermogenesis. ${ }^{12}$ Although the food ingredients are not as potent as drugs, they have the advantage of fewer adverse side effects and thus may represent interesting complementary approaches to the management of obesity. There is increasing evidence to indicate a beneficial role for dietary polyphenols in reducing obesity, and this subject has been extensively reviewed. ${ }^{13-19}$ However, despite the abundance of proanthocyanidins (PA) in nature, few papers have addressed the specific effects of these compounds on obesity. This lack of data is almost certainly due to the high structural diversity and complexity of this class of dietary components and to the difficulty to separate them from monomers and other phenolic compounds. Here, we review the role of PA rich extracts with respect to obesity, focusing on mass and body weight, energy intake, glucose and lipid metabolism and energy expenditure.

\section{Proanthocyanidins structure and bioavailability}

PA, also known as condensed tannins, are the most common group of flavonoids in the Western diet, and they are considered the second most abundant group of natural phenolics after lignins. ${ }^{20}$ The data available for adults from fourteen European countries indicated that the daily PA intake was highest in Spain and lowest in The Netherlands. Conversely, the highest intakes of flavan-3-ol monomers and theaflavins were observed in Ireland and the lowest intakes in Spain. ${ }^{21}$ U.S. adults had a total PA intake of $95 \mathrm{mg}$ per day, in the order of polymers $(30 \%)$, monomers $(22 \%)$, dimers $(16 \%)$, trimers (5\%), 4-6 mers (15\%), and 7-10 mers $(11 \%) .{ }^{22}$ PA can be found in such common foodstuffs as cereals, legumes, fruits, vegetables, and beverages as red wine and tea. ${ }^{23,24} \mathrm{PA}$ are oligomers or polymers of monomeric flavan-3-ols. A flavan-3-ol unit has two aromatic rings (A and $\mathrm{B}$ ) and a heterocyclic ring $\mathrm{C}$. The monomers are mainly linked through $\mathrm{C} 4$ to $\mathrm{C} 8$ or sometimes C4 to C6 bonds. These linkages are both called B-type linkages. When an additional ether linkage is formed between $\mathrm{C} 2$ and $\mathrm{O} 7$, the compounds are called A-type PA. In addition to the $\mathrm{C} 2$ to $\mathrm{O} 7$ linkage, A-types with a $\mathrm{C} 2$ to $\mathrm{O} 5$ linkage are also found. The two chiral centres at $\mathrm{C} 2$ and $\mathrm{C} 3$ of the monomeric flavan-3-ol produce four isomers for each level of B-ring hydroxylation. ${ }^{25}$ Oligomeric and polymeric $\mathrm{PA}$ have an additional chiral centre at $\mathrm{C} 4$ in the upper and lower units. The PA are divided into sub-families: Procyanidins consist exclusively of (+)-catechin and (-)-epicatechin and are widespread in nature. PA containing afzelechin or gallocatechins are called propelargonidins or prodelphinidins, respectively, and have a more limited distribution. Many common foods such as grape seeds, cocoa, apples, pears, blueberries, and cranberries contain exclusively procyanidins. Some of the PA in strawberries and pinto beans are propelargonidins. Some of the PA in grape skins are prodelphinidins, while the rest are procyanidins. $^{26}$ 5-Deoxysubunits (robinetinidol or fisetinidol) are also known. ${ }^{27}$ Flavan-3-ols predominantly exist in plants as 3-O-gallate forms.

No transporters for PA have been identified on the enterocyte surface of the small intestine. Paracellular diffusion is thought to be the preferred absorption mechanism because PA are not likely to pass through the lipid bilayer via the transcellular pathway due to their large numbers of hydrophilic hydroxyl groups. ${ }^{28}$ Deprez et al. observed that (+)-catechin (CA) and the procyanidin dimer and trimer had similar permeability coefficients to that of mannitol, a marker of paracellular transport, in monolayers of the human intestinal epithelial cell line, Caco-2. ${ }^{29}$ A transport rate of a $3.0 \%$ was shown for procyanidin $\mathrm{B} 2 .{ }^{30}$ The results from the in in vivo models demonstrated that PA oligomers with a degree of polymerisation less or equal than 3 are absorbable. ${ }^{31-33}$ The bioavailability of PA is largely influenced by the degree of their polymerisation. Both human and animal studies have indicated that (+)-catechin and (-)-epicatechin (EC) are rapidly absorbed from the upper portion of the small intestine. Upon absorption, (epi)catechin undergoes extensive phase II metabolism in the intestine and liver to form glucuronidated, sulphated, and/or methylated conjugates. The current knowledge indicates that PA dimers, and trimers are absorbed in their intact forms, and their absorption rates are less than $10 \%$ of that of (-)-EC. In rats, the absorbed oligomers undergo less phase II metabolism than (-)-EC. ${ }^{28}$ Furthermore, in an in vitro study, EC and epicatechin gallate (ECG) were largely or completely converted to glucuronides, sulphates and methyl ethers. In contrast, glucuronidation and methylation of procyanidins B2 and the 3,3"-di-O-galloyl ester of procyanidin B2 (B2G2) occurred, but were minor processes under the same incubation conditions. When B2G2 was given orally to mice, it was partially absorbed intact: no significant metabolites were detected in plasma. Therefore, B2G2 bioavailability is apparently not limited by metabolism, unlike the flavanol monomers EC and ECG. ${ }^{34}$ In another study with pigs, which have a gastrointestinal tract very similar to that of humans, urinary excretion and metabolism of PA were investigated. A reduced grape seed extract containing monomers and procyanidins B1, B2, B3, B4, C1, was orally administered at a dose of $250 \mathrm{mg}$ per $\mathrm{kg}$ body weight. Flavan-3-ols and their methyl derivatives, as well as dimeric and trimeric procyanidins were detectable in the urine. The quantification of PAs in the urine showed that excretion depends on the degree of polymerisation. The excretion was very poor for dimeric and trimeric procyanidins, with the total amount varying between 14 and $20 \mu \mathrm{g}$ for the dimeric procyanidins and being approximately $5 \mu \mathrm{g}$ for procyanidin $\mathrm{C} 1 .^{31}$ Many other studies show that these compounds are present in blood and tissues..$^{32,33,35-42}$ Interestingly, there is evidence that unconjugated PA and their metabolites cross the blood brain barrier. ${ }^{43-46}$ There is some controversy regard- 
ing whether oligomeric and polymeric PA can be degraded into smaller units during the passage through the gastrointestinal tract. Some studies observed a degradation of oligomeric PAs into flavan-3-ols in simulated gastric juice ${ }^{47}$ and before being absorbed. ${ }^{48,49}$ Conversely, studies in humans ${ }^{50,51}$ and rats $^{36,52,53}$ showed that depolymerisation in the gastrointestinal tract was negligible, and PA were stable during gastric transit. As a result, oligomers and polymers did not contribute to the concentration of monomers in blood or urine. Ou et al. $(2014)^{28}$ in a recent review stated that the majority of the PA reaches the colon intact and is degraded into phenylvalerolactones and phenolic acids by the colon microbiota. Some of the products of this degradation could have higher biological activity than their parent compounds. ${ }^{54}$ Non-absorbed large PA can interact with intestinal membranes, protecting the bilayer structure, mitigating oxidative stress, and regulating barrier permeabilisation and cytokine-induced inflammation. ${ }^{5,56}$ The data from tissue analysis of rats gavaged with grape seed extract indicate fairly high accumulation of native compounds, primarily monomers and dimers, in the cecum and colon. ${ }^{57}$ Additionally, administration of $0.25 \%(w / w)$ GSE to rats showed that the concentration in the colonic contents was $13.9 \mathrm{mg} \mathrm{kg}^{-1}$ for monomer, and those for the dimers through hexamers were $33.4,84.6,87.2,57.3$, and $35.7 \mathrm{mg}$ $\mathrm{kg}^{-1}$, respectively. ${ }^{58}$ Thus, despite the extensive PA biotransformation by the gut microbiota, the ingested PA were present in the colon as the intact parent compounds and thus may contribute to the colon metabolic status. Furthermore, Cueva et al. $(2013)^{59}$ showed that two purified fractions from grape seed extract, differing in their proportions of monomers and procyanidins, both promote the growth of potentially beneficial bacteria (Lactobacillus sp.) and decreased the growth of undesirable bacteria such as clostridia, to the same extent as observed in an in vitro experiment. Accordingly, microbial catabolic activity could change and consequently could affect the bioavailability and activity of these compounds. PA have a putative role as antioxidants, ${ }^{60-63}$ showing beneficial effects on inflammatory processes, cardiovascular diseases, and other pathological conditions. ${ }^{64,65}$

\section{Effects of PA on fat and body weight}

When hamsters were treated with a grape seed procyanidin extract (GSPE) for 15 days and fed either a standard diet (STD) or a high-fat diet (HFD), both groups showed a significant decrease in body weight gain and in the weight of white adipose tissue (WAT) depots studied. This effect was more evident in the retroperitoneal WAT than in the other adipose tissues. Also the effect of the GSPE treatment was more clear in the HFD-GSPE than in the STD-GSPE animals, in comparison with their respective non-treated controls, mesenteric WAT: STD-GSPE (9.8\% lower), HFD-GSPE (18.8\% lower); epididymal WAT: STD-GSPE (8.8\% lower), HFD-GSPE (16.6\% lower); inguinal WAT: STD-GSPE $(10.5 \%$ lower $)$, HFD-GSPE $(16 \%$ lower). ${ }^{66}$ Furthermore, polyphenols from red wine can reduce obesity in rats. ${ }^{67}$ In mice fed a HFD, supplements consisting of either a cocoa flavanol extract or a flavanol fraction enriched with monomeric, oligomeric, or polymeric procyanidins prevented weight gain, increases in fat mass, impairment of glucose tolerance, and insulin resistance.$^{68}$ The oligomer-rich fraction proved to be the most effective in this model. Matsui et al. showed that cocoa supplementation for 3 weeks significantly decreased weight gain in HFD-rats compared to HFDcontrols. Thus, the rate of body weight changes (\%initial weight) was $151.2 \pm 3.3$ for HFD + cocoa and $164.8 \pm 5.1$ for HFD. Also mesenteric WAT (\%body weight) was lower when HFD was supplemented with cocoa: $0.683 \pm 0.153$ vs. $0.838 \pm$ $0.131{ }^{69}$ A PA-rich fraction of Cassia nomame fruits (CTII) was effective in preventing and ameliorating obesity. Thus, CT-II significantly inhibited body weight gain (shown as percentage of initial body weight): $28.10 \pm 3.01$ for HFD $v s .16 .76 \pm 2.95$ for HFD $+2.5 \%$ CTII, without affecting food intake in lean rats. ${ }^{70}$ When obese rats fed the HFD were treated with CT-II for up to 6 months, body weight was initially reduced and thereafter weight gain was significantly suppressed. Total body fat (as a percentage of final body weight) in rats fed the HFD without CT-II, those fed the diet with 12 weeks treatment of CT-II and those fed a normal diet were $49 \%, 37 \%$ and $27 \%$, respectively. The supplementation with a drink containing a PA-enriched fraction of the seed shells of Japanese horse chestnut (Aesculus turbinata BLUME) was found to attenuate the body weight gain and reduce the mass of peritoneal adipose tissues in mice fed a HFD, despite the fact that the amount of food consumption and the volume of the fluid intake did not change significantly. ${ }^{71}$ Thus, while the HF mice weighed approximately $32 \mathrm{~g}$ more than their standard fed counterparts, the body weight of $\mathrm{HF}+0.52 \%$ PA mice increased only in 20 g. ${ }^{71}$ Similarly, the mass of peritoneal adipose tissues $(\mathrm{g})$ was $15.50 \pm 1$ for HFD group and $4.32 \pm 0.46$ for HFD $+0.52 \%$ PA group. Ikarashi et al. (2011) demonstrated an anti-obesity activity of a bark extract of the black wattle tree (Acacia meansii) in mouse models. PA constitute $68 \mathrm{wt} \%$ of this bark extract, which is rich in unique catechin-like flavan-3-ols, such as robinetinidol and fisetinidol. The addition of the extract to a highfat diet was found to significantly suppress increases in body weight $(\mathrm{g})$ : HFD $(20.5 \pm 2.0)$, HFD $+2.5 \%$ PA $(14.2 \pm 4.3)$, HFD $+5.0 \%$ PA $(8.4 \pm 1.9)$, and in WAT weight $(g):$ HFD (4.66 \pm $0.34)$, HFD $+2.5 \%$ PA $(4.00 \pm 0.35)$, HFD $+5.0 \%$ PA $(3.37 \pm$ $0.54) .{ }^{72}$ The simultaneous supply of GSPE ( $30 \mathrm{mg} \mathrm{kg}^{-1}$ per day) to rats fed a $60 \% \mathrm{kcal}$ fat diet for 19 weeks reduced body weight, but no changes were found in the weight of fat depots. ${ }^{73}$ Likewise, simultaneous GSPE administration $(25 \mathrm{mg}$ per $\mathrm{kg}$ for 21 days) protects cafeteria diet (CD) fed rats against weight gain. ${ }^{74}$ Hence, there are studies with different animal models and with PA rich extracts from different sources, indicating that PA reduces fat and body weight. In fact, PA appears to reduce the body weight gain rather than to reduce the body weight. Conversely, other studies have shown no improvement in adiposity and body weight following PA administration. ${ }^{75-81}$ Thereby, female Wistar rats fed a CD for 13 weeks were divided into subgroups; one of which was treated with GSPE $(25 \mathrm{mg}$ 
$\mathrm{kg}^{-1}$ ) for 10 days. The other one was treated with $50 \mathrm{mg}$ GSPE per $\mathrm{kg}$ for 20 days. None of these treatments produced a significant reduction in body weight. ${ }^{24,73}$ Also no changes in body weight of male obese (fa/fa) and lean (Fa/?) Zucker rats were shown after GSPE administration for 30 days. $^{76}$ As far as we know, only an human study in over 1000 American men and women showed a negative correlation between the frequency of chocolate consumption, and body mass index $(P=$ 0.01 ), although no data on eaten doses were shown in ref. 82 . In conclusion, the PA effects on adiposity and body weight are controversial in animal experiments. There are studies where administration of PA extracts prevent or inhibit the body weight gain whereas other studies did not show the same effects. This could be due to different experimental models, doses, and times used.

\section{Nutrient intake control by proanthocyanidins}

\section{Inhibition of digestive enzymes}

In the treatment of obesity, the development of inhibitors of nutrient digestion and absorption is one of the main strategies in the effort to reduce energy intake through gastrointestinal mechanisms without altering the central mechanisms. ${ }^{83}$ Horigome et al. reported that PA from various plants had inhibitory effects on digestive enzymes such as trypsin, a-amylase, and lipase. ${ }^{84}$ These enzymes are delivered into the intestinal lumen as constituents of the pancreatic juices and are the major enzymes involved in the hydrolysis of dietary protein, starch and fat. The inhibitory effects of PA on the digestive enzymes is considered to be one mechanism through which they exert their effects. ${ }^{85}$ Because digestive enzymes are located in the small intestine, and PA are predominantly metabolised in the colon, it was expected that the presence of PA in the small intestinal lumen would be sufficient to inhibit these enzymes following the consumption of a PA-rich food.

\section{Lipase}

Proanthocyanidins from different sources have inhibitory activities on lipase (Table 1). Hatano et al. (1997) isolated five flavan dimers from fruits of Cassia nomame that showed lipase-inhibiting effects. Among the flavan dimers tested, $(2 S)$ -

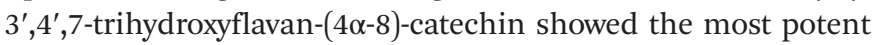
lipase-inhibitory activity. C. nomame extract also showed antiobesity effects in rats fed with HFD in vivo. ${ }^{86} \mathrm{~A}$ partially purified fraction composed of oligomeric flavans with molecular weight 1020 also showed a noticeable inhibitory effect. ${ }^{87}$ An extract of Nomame Herba inhibited lipase activity in a dosedependent manner, with approximately $0.1 \mathrm{mg} \mathrm{mL}^{-1}$ of extract resulting in $50 \%$ inhibition. A small part of the active components of lipase inhibitors were confirmed to be $3^{\prime}, 4^{\prime}, 7$-trihydroxyflavan-( $4 \alpha-8)$-catechin, and the major active components were suggested to be $3^{\prime}, 4^{\prime}, 7$-trihydroxyflavan oligomers. ${ }^{70}$ An apple polyphenol extract (AP) and the procyanidin contained in AP substantially inhibited pancreatic lipase (PL) activity and reduced triglyceride absorption. ${ }^{88}$ However, other non-procyanidin polyphenols in AP (i.e., catechins, chalcones, and phenol carboxylic acids) showed weak inhibitory effects on PL. Furthermore, the inhibitory effects of the procyanidins increased according to the degree of polymerisation (DP) from dimer to pentamer. Similarly, procyanidins with DPs of pentamer or greater showed maximal inhibitory effects on PL. ${ }^{88}$ Subsequent studies have confirmed a clear relationship between the procyanidin DP and their inhibitory activities on pancreatic lipase. For example, the inhibition of lipase activity by fractions of grape seed procyanidins (Vitis vinifera) ${ }^{89}$ and of cocoa (Theobroma cacao) extracts also increased with the increasing $\mathrm{DP}$, where an inverse correlation between $\log \mathrm{IC}_{50}$ and $\mathrm{DP}\left(R^{2}>\right.$ 0.93) was observed..$^{90}$ Thus, in this case as well, higher levels of DP were associated with more potent inhibitory activities of the procyanidins. In the leaf fraction of Salacia reticulata, a plant used to prevent diabetes and obesity, the most potent PL-inhibition activity $\left(\mathrm{IC}_{50}: 15 \mathrm{ppm}\right)$ was shown to be due to the PA oligomers (DP: 3-8) composed of EGC, EC, and epiafzelechin as main constituents. ${ }^{91}$ The $\mathrm{IC}_{50}$ value for the active compound from the $S$. reticulata leaf extract was comparable to that of epigallocatechin gallate (EGCG), which is known to be one of the more effective lipid-lowering therapeutic agents. ${ }^{92}$ Kimura et al. (2011), in addition to analysing the effect of the DP, studied the effect of the PA-linkage type in the inhibition exerted on PL activity. Highly polymeric PA from seed shells of Japanese horse chestnut (Aesculus turbinata Blume) were separated into two fractions according to the difference in the molecular sizes. The results of this structural characterisation, in terms of the molecular sizes and the proportions of A-type linkages relative to B-type linkages, were compared to those of the corresponding preparations from fruits of blueberry and cranberry. The rank order of the molecular sizes of the PA was blueberry $>$ cranberry $>$ seed shells of the Japanese horse chestnut. The analysis of the degradation products revealed higher proportions of A-type linkages compared with B-type linkages in the both isolated fractions in the order of the seed shells $>$ cranberry $>$ blueberry. Moreover, the isolated fractions with higher molecular sizes and those more abundant in the proportions of A-type linkages were found to be more effective in the inhibition of PL activity. ${ }^{93}$ An oral fat tolerance test in mice revealed that these polymeric PA suppressed fat digestion in vivo. An extract of the bark of Acacia mearnsii also showed strong lipase inhibitory activity. Fractionation of this extract and subsequent analysis revealed that the active substances were PA oligomers mainly composed of 5-deoxyflavan-3-ol units. In addition, 4'-O-methylrobinetinidol 3'-O- $\beta$-D-glucopyranoside, fisetinidol-(4R,6)-gallocatechin, and epirobinetinidol$(4 \beta, 8)$-catechin were isolated as new compounds. The characterisation of the most active fraction showed that it contained tetrameric to octameric compounds primarily composed of robinetinidol units. ${ }^{94}$

Consistent with the lipase inhibition effects demonstrated in vitro, in vivo studies showed that PA actively reduced plasma triglycerides by inhibiting the absorption of dietary lipids. ${ }^{24}$ Furthermore, polyphenols from red wine can delay the absorp- 
Table 1 Lipase activity inhibition by proanthocyanidins in in vitro experiments ${ }^{a}$

\begin{tabular}{|c|c|c|c|c|c|c|}
\hline Source. Substrate (S) used for PL activity & Main PAC constituents & $\begin{array}{l}\text { Average } \\
\text { DP }\end{array}$ & $\begin{array}{l}\text { Linkage } \\
\text { type }\end{array}$ & Lipase IC50 & $\begin{array}{l}\text { PLA2 } \\
\text { IC50 }\end{array}$ & Ref. \\
\hline $\begin{array}{l}\text { Cassia nomame (fruit). S: } \\
\text { 4-methyl-umbelliferyl oleate. }\end{array}$ & $\begin{array}{l}\text { 3',4',7-trihydroxy flavan-CA; } \\
\text { B3; (-)-fisetinidol-CA; } \\
\text { (+)-fisetinidol-CA }\end{array}$ & 2 & $\begin{array}{l}\mathrm{C} 4 \alpha-8 \\
\mathrm{C} 4 \beta-8\end{array}$ & $5.5 \mu \mathrm{M}$ & & 87 \\
\hline $\begin{array}{l}\text { Cassia mimosoides (aerial part of } \\
\text { dried plant). S: Triglycerides }\end{array}$ & $3^{\prime}, 4^{\prime}, 7$-trihydroxy flavan-CA & & $\mathrm{C} 4 \alpha-8$ & $0.1 \mathrm{mg} \mathrm{mL} \mathrm{L}^{-1}$ & & 70 \\
\hline Malus domestica (fractions according to & $\mathrm{EC}, \mathrm{CA}$ & 2 & & $>125 \mu \mathrm{g} \mathrm{mL}{ }^{-1}$ & & 88 \\
\hline & & 5 & & $1.3 \mu \mathrm{g} \mathrm{mL}^{-1}$ & & \\
\hline & & 6 to $>9$ & & $0.7-2.3 \mu \mathrm{g} \mathrm{mL}^{-1}$ & & \\
\hline & & PA extract & & $1.4 \mu \mathrm{g} \mathrm{mL}-1$ & & \\
\hline $\begin{array}{l}\text { Vitis vinifera (grape seed). S: } \\
p \text {-nitrophenyl } \\
\text { caprylate. Inhibition by } 3 \text { fractions of the } \\
\text { extract with different } M_{\mathrm{w}} \text { was evaluated }\end{array}$ & EC, CA, ECG, CAG & & & & & 89 \\
\hline Lavado (unfermented) & & & & $47.0 \mu \mathrm{g} \mathrm{mL}{ }^{-1}$ & $8.5 \mu \mathrm{g} \mathrm{mL}{ }^{-1}$ & \\
\hline Regular (fermented) & & & & $57.7 \mu \mathrm{g} \mathrm{mL}^{-1}$ & $19.7 \mu \mathrm{g} \mathrm{mL}{ }^{-1}$ & \\
\hline Dutch processed & & & & $1720.4 \mu \mathrm{g} \mathrm{mL} \mathrm{m}^{-1}$ & - & \\
\hline (fermented \& alkalinized) & & & & & & \\
\hline Aesculus turbinata (seeds). & EC, CA, EGC & 76.7 & A-highest (37\%) & $1.0 \mu \mathrm{g} \mathrm{mL}{ }^{-1}$ & & 93 \\
\hline S: 4-methyl-umbelliferyl oleate & & 167.5 & A-highest (29\%) & $0.29-0.34 \mu \mathrm{g} \mathrm{mL}^{-1}$ & & \\
\hline Vaccinium macrocarpon (fruit). & & 74.7 & A-high (25\%) & $1.5 \mu \mathrm{g} \mathrm{mL} L^{-1}$ & & \\
\hline S: 4-methyl-umbelliferyl oleate & & 118.7 & A-high $(20 \%)$ & $0.29-0.34 \mu \mathrm{g} \mathrm{mL} \mathrm{m}^{-1}$ & & \\
\hline Vaccinium angustifolium (fruit). & & 183.0 & A-low (7\%) & $1.5 \mu \mathrm{g} \mathrm{mL}-1$ & & \\
\hline S: 4-methyl-umbelliferyl oleate & & 459.7 & A-low (6\%) & $0.29-0.34 \mu \mathrm{g} \mathrm{mL}^{-1}$ & & \\
\hline $\begin{array}{l}\text { Acacia mearnsii (bark). S: a mixture of } \\
\text { glyceryl trioleate, lecithin, and } \\
\text { sodium cholate. }\end{array}$ & $\begin{array}{l}\text { Robinetinidol, GC, CA, } \\
\text { Robinetinidol-GC, } \\
\text { Robinetinidol-CA, } \\
\text { Fisetinidol-CA }\end{array}$ & $(4-8)$ & & $80 \mu \mathrm{g} \mathrm{mL}{ }^{-1}$ & & 94 \\
\hline
\end{tabular}

tion of dietary fat in humans, ${ }^{95}$ and polymerised polyphenols from oolong tea reduced postprandial hyper-triglyceridaemia in olive oil-loaded rats and mice. ${ }^{96}$ In corn oil-loaded mice, a single oral administration of apple polyphenols reduced the plasma triglyceride levels, and a test diet containing $600 \mathrm{mg}$ of apple polyphenols significantly inhibited the increases in triglyceride $6 \mathrm{~h}$ after ingestion, indicating an inhibition of triglyceride absorption. ${ }^{88}$

\section{Amylase}

Table 2 shows the inhibitory effect of PA on amylase and smaller oligosaccharide-digesting enzymes. Lee et al. (2007) evaluated the anti- $\alpha$-amylase and anti- $\alpha$-glucosidase effects of the polymers and oligomers from PA of persimmon peel. The polymers strongly inhibited the $\alpha$-amylase activity, while the oligomers had a relatively weak effect. At a concentration of $100 \mu \mathrm{g} \mathrm{mL}{ }^{-1}$, the polymers and oligomers inhibited $53.9 \%$ and $4.6 \%$ of the $\alpha$-amylase activity, respectively. In contrast, the oligomers showed a stronger inhibition of $\alpha$-glucosidase activity than the polymers. At a concentration of $100 \mu \mathrm{g} \mathrm{mL}{ }^{-1}$, the polymers and oligomers inhibited $74.0 \%$ and $97.4 \%$ of the $\alpha$-glucosidase activity, respectively. ${ }^{64}$ The stems of $P$. multiflorum contain high amounts of PA, predominantly composed of CA and/or EC units and with a mean DP of 32.5. These PA exhibit potent $\alpha$-amylase and moderate $\alpha$-glucosidase inhibitory activities. ${ }^{97}$ An analysis of the PA isolated from Manilkara zapota (chiku) showed that (epi)gallocatechins were the predominant extension unit in the PA. The mean of the degree of polymerisation was estimated to be 9.0. These PA were shown to inhibit $\alpha$-amylase with an IC50 value of $4.2 \pm 0.2 \mu \mathrm{g} \mathrm{mL} \mathrm{m}^{-1}$ and inhibit $\alpha$-glucosidase with an IC50 of $16.6 \pm 0.3 \mu \mathrm{g} \mathrm{mL}^{-1} .{ }^{98}$ Different berries showed very different levels of effectiveness against $\alpha$-amylase activity and $\alpha$-glucosidase activity, and a comparison of their polyphenol composition indicated which components were the most effective inhibitors. The extract from rowanberries was particularly potent with an IC50 value of $4.5 \mu \mathrm{g} \mathrm{GAE} \mathrm{mL} \mathrm{L}^{-1}$. Only the PA-rich fraction caused a substantial inhibition of amylase and yielded an IC50 value of $\sim 5 \mu \mathrm{g}$ GAE $\mathrm{mL}^{-1}$ compared to $4.5 \mu \mathrm{g}$ GAE $\mathrm{mL}^{-1}$ for the unfractionated rowanberry extract. ${ }^{99}$ The rowanberry PA were as 
Table $2 \alpha$-Amylase and $\alpha$-glucosidase inhibition activity by proanthocyanidins in in vitro experiments

\begin{tabular}{|c|c|c|c|c|c|c|}
\hline $\begin{array}{l}\text { Source. Substrate (S) used for } \\
\text { amylase activity }\end{array}$ & Main PAC constituent & $\begin{array}{l}\text { Average } \\
\text { DP }\end{array}$ & $\begin{array}{l}\text { Linkage } \\
\text { type }\end{array}$ & $\begin{array}{l}\text { Amylase } \\
\text { IC50 }\end{array}$ & $\begin{array}{l}\text { Glucosidase } \\
\text { IC50 }\end{array}$ & Ref. \\
\hline $\begin{array}{l}\text { Persimmon (peel). S: } \\
p \text {-nitro-phenyl- } \alpha-\mathrm{D}^{-} \\
\text {glucopyranoside (pNPG) }\end{array}$ & EGC, EGCG, EC, ECG & & $\begin{array}{l}\mathrm{B}(\mathrm{C} 4-\mathrm{C} 8 \\
\mathrm{C} 4-\mathrm{C} 6)\end{array}$ & & & 64 \\
\hline Oligomer & & 3.3 & & - & $5 \mu \mathrm{g} \mathrm{mL}^{-1}$ & \\
\hline Polymer & & $>3.3$ & & $100 \mu \mathrm{g} \mathrm{mL}^{-1}$ & - & \\
\hline $\begin{array}{l}\text { Garcinia mangostana } \\
\text { (pericarp). S: gelatinized } \\
\text { starch }\end{array}$ & EC & $2-10$ & B & $5.4 \mu \mathrm{g} \mathrm{mL} \mathrm{m}^{-1}$ & - & 188 \\
\hline $\begin{array}{l}\text { Pycnogenol } ® \text { (maritime } \\
\text { pine bark). S: pNPG }\end{array}$ & $\mathrm{CA}$ & $>2$ & & - & $5 \mu \mathrm{g} \mathrm{mL}^{-1}$ & 189 \\
\hline $\begin{array}{l}\text { Diospyros kaki (leaves). } \\
\text { S: soluble starch }\end{array}$ & CA, EGC, EGCG, EC, ECG & $(6-8)$ & & $48 \mu \mathrm{g} \mathrm{mL} \mathrm{L}^{-1}$ & & 100 \\
\hline $\begin{array}{l}\text { Acacia mearnsii (bark). } \\
\text { S: starch }\end{array}$ & Robinetinidol & $(4-8)$ & & $38 \mu \mathrm{g} \mathrm{mL} L^{-1}$ & - & 94 \\
\hline $\begin{array}{l}\text { Sorghum bicolor (bran). } \\
\text { S: starch }\end{array}$ & & & & $1.4 \mu \mathrm{g} \mathrm{mL}^{-1}$ & - & 190 \\
\hline $\begin{array}{l}\text { Manilkara zapota (fresh } \\
\text { peeled chiku). S: starch }\end{array}$ & EGC, EC, EGCG & 9.0 & B & $4.2 \mu \mathrm{g} \mathrm{mL}^{-1}$ & $16.6 \mu \mathrm{g} \mathrm{mL}{ }^{-1}$ & 98 \\
\hline $\begin{array}{l}\text { Vitis vinifera (grape seed). } \\
\text { S: starch \& pNPG }\end{array}$ & $\mathrm{CA}, \mathrm{EC}, \mathrm{ECG}, \mathrm{B} 1, \mathrm{~B} 2, \mathrm{C} 1$ & $(2-3)$ & & $8.7 \mu \mathrm{g} \mathrm{mL}^{-1}$ & $1.2 \mu \mathrm{g} \mathrm{mL}^{-1}$ & 104 \\
\hline Green Tea. S: starch \& pNPG & $\begin{array}{l}\text { CA, EC, EGC, ECG, EGCG, } \\
\text { GCG, GC, CG }\end{array}$ & n.d. & & $34.9 \mu \mathrm{g} \mathrm{mL}{ }^{-1}$ & $0.5 \mu \mathrm{g} \mathrm{mL}^{-1}$ & 105 \\
\hline White Tea. S: starch \& pNPG & $\begin{array}{l}\text { CA, EC, EGC, ECG, EGCG, } \\
\text { GCG, GC, CG }\end{array}$ & n.d & & $378 \mu \mathrm{g} \mathrm{mL}^{-1}$ & $2.5 \mu \mathrm{g} \mathrm{mL}^{-1}$ & 105 \\
\hline Rowanberry (fruit). S: starch & EC & & A, B & $5 \mu \mathrm{g} \mathrm{GAE} \mathrm{mL}^{-1}$ & $>200 \mu \mathrm{g}$ GAE $\mathrm{mL}^{-1}$ & 99 \\
\hline $\begin{array}{l}\text { Polygonum multiflorum } \\
\text { (stems). S: starch }\end{array}$ & $\mathrm{CA}, \mathrm{EC}$ & 32.6 & & $2.9 \mu \mathrm{g} \mathrm{mL}{ }^{-1}$ & $7.4 \mu \mathrm{g} \mathrm{mL}{ }^{-1}$ & 97 \\
\hline $\begin{array}{l}\text { Prunus dulcis (roasted } \\
\text { almond seed skin). S: starch }\end{array}$ & CA, EC, EGC, GC & $(2-11)$ & $\mathrm{A}, \mathrm{B}$ & $2.2 \mu \mathrm{g} \mathrm{mL}^{-1}$ & & 103 \\
\hline $\begin{array}{l}\text { Arachis hypogaea (peanut } \\
\text { skin). S: maltose \& sucrose }\end{array}$ & $\begin{array}{l}\text { CA, EC, procyanidins A1, A2, } \\
\text { epicatechin- }(2 \beta \rightarrow O \rightarrow 7,4 \beta \rightarrow 8)- \\
\text { ent-epicatechin, } \\
\text { epicatechin- }(2 \beta \rightarrow O \rightarrow 7,4 \beta \rightarrow 6) \text {-catechin, } \\
\text { cinnamtannin B1, epicatechin- } \\
(2 \beta \rightarrow O \rightarrow 7,4 \beta \rightarrow 8) \text {-catechin- }(6 \rightarrow 4 \beta)- \\
\text { epicatechin, epicatechin- }(4 \beta \rightarrow 8) \text { - } \\
\text { epicatechin- }(2 \beta \rightarrow O \rightarrow 7,4 \beta \rightarrow 8) \text {-catechin }\end{array}$ & 2,3 & A & & $88 \mu \mathrm{g} \mathrm{mL} L^{-1}$ (maltase) & 191 \\
\hline $\begin{array}{l}\text { Acacia mearnsii (bark). } \\
\text { S: maltose \& sucrose }\end{array}$ & Robinetinidol, Fisetinidol & & & & $\begin{array}{l}91 \mu \mathrm{g} \mathrm{mL}^{-1} \text { (sucrase) } \\
0.22 \mathrm{mg} \mathrm{mL}^{-1} \text { (maltase) } \\
0.60 \mathrm{mg} \mathrm{m}^{-1} \text { (sucrase) }\end{array}$ & 187 \\
\hline
\end{tabular}

potent inhibitors as the whole rowanberry extract, despite the fact that this fraction was at least ten-fold enriched in PA compared to the original rowanberry extract. This suggests that the presence of the other non-PA components may have influenced the amylase inhibition. Polyphenol-rich extracts from black currants were effective inhibitors of $\alpha$-glucosidase with an IC50 value of $20 \mu \mathrm{g}$ GAE $\mathrm{mL}^{-1}$. On the other hand, raspberry and cloudberry extracts were poor inhibitors. The rowanberry PA fraction was considerably less effective than the whole rowanberry extract in its ability to inhibit $\alpha$-glucosidase. These differences in the efficacy of amylase inhibition suggest that these tannin components do not influence the inhibition of $\alpha$-glucosidase. Boath et al. (2012) ${ }^{99}$ concluded from these studies that PA were effective against amylase but ineffective against $\alpha$-glucosidase. The major components of a persimmon leaf extract were PA oligomers, which had considerable concentration-dependent $\alpha$-amylase inhibitory activity. ${ }^{100}$ A structural investigation revealed that the persimmon leaf PA have three distinguishing characteristics. First, their extension units consist of 4 different units, EGC, EGCG EC, and ECG, indicat- ing higher heterogeneity than for other PA, which consist of only 1-3 different units. Second, more than $40 \%$ of the content of this extract consisted of prodelphinidins: a considerably higher proportion than the levels of these compounds in grape skins $(31.2 \%) .{ }^{101}$ Third, the degree of 3-O-galloylation was $9-14 \%$, similar to the $12.9 \%$ reported for grape seeds. ${ }^{101}$ Increases in galloylation have been suggested to lead to the enhanced physicochemical and physiological effects of PA, e.g., increased affinity to proteins, including enzymes. ${ }^{102}$ Oral administration of starch with PA from persimmon leaf tea resulted in a significant and dose-dependent decrease in the blood glucose concentrations in Wistar rats. This effect was considered to be due to inhibition of pancreatic $\alpha$-amylase. ${ }^{100}$ Tsujita et al. (2013) showed that a purified fraction from almond (Prunus dulcis) seed skin specifically and strongly inhibited $\alpha$-amylase: the IC50 value was $2.2 \mu \mathrm{g} \mathrm{mL}$ for pig pancreatic $\alpha$-amylase. The structure of this fraction includes a series of polyflavan-3-ol polymers composed of CA/ EC units and GCA/EGCA units, with up to 11 units with several A-type ether linkages. $\alpha$-Amylase from Bacillus sp. was inhib- 
ited in a concentration-dependent manner with an IC50 value approximately 23 times higher than that of pig pancreatic $\alpha$-amylase. These results suggested that the purified fraction specifically and strongly inhibited the mammalian digestive $\alpha$-amylase. ${ }^{103}$ Yilmazer-Musa et al. (2012) evaluated the inhibitory effects of plant-based extracts (grape seed, green tea, and white tea) and their constituent flavan-3-ol monomers (catechins) on $\alpha$-amylase and $\alpha$-glucosidase activity. To evaluate the relative potency of the extracts and catechins, the concentrations of each required to inhibit 50 and $90 \%$ of the enzyme activity were determined and compared to the widely used pharmacological glucosidase inhibitor, acarbose. The maximum enzyme inhibition was used to assess relative inhibitory efficacy. The results showed that the grape seed extract strongly inhibited both $\alpha$-amylase and $\alpha$-glucosidase activity, with equal and much higher potency, respectively, than acarbose. Whereas the tea extracts and catechin 3-gallates were less effective inhibitors of $\alpha$-amylase, they were potent inhibitors of $\alpha$-glucosidase. Non-gallated catechins were ineffective. These data show that plant extracts containing catechin 3-gallates, in particular EGCG, are potent inhibitors of $\alpha$-glucosidase activity and suggest that the procyanidins in grape seed extract strongly inhibit $\alpha$-amylase activity. ${ }^{104}$ Barrett et al. (2013) isolated PA from extracts of cranberries, grapes, and cocoa and tested the effectiveness of these isolates to inhibit the activities of $\alpha$-amylase and glucoamylase in vitro. The PA inhibition efficacy followed the orders cranberry > grape $>$ cocoa for $\alpha$-amylase and grape $>$ cranberry $>$ cocoa for glucoamylase. These results correlate with structural differences among the PA. Thus, the cocoa PA, which were the smallest and least complex of the tannins, had the least effect on the activity of either enzyme. The structural complexity or size, such as the A-type linkages and high degree of polymerisation in the PA from cranberries, may have been conformational features adequate for their high enzyme inhibition. The grape extract was also highly effective in the inhibition of both enzymes, despite the smaller size of the PA in this extract relative to that from the cranberries. This isolate, however, exhibited comparatively greater diversity, including a higher proportion of trimer units, than did the extract from cocoa. In general, the larger and more complex the tannins, the more effectively they inhibited the enzymes. ${ }^{105}$
These in vitro results are supported by oral glucose tolerance tests in animals and by a limited number of human intervention studies. ${ }^{106}$ Kimura et al. (2011) evaluated the effects of two isolated fractions of highly polymerised PA from seed shells on an oral starch or glucose tolerance test in mice. These two fractions had different degree of polymerisation. However, both effectively suppressed the elevation of blood glucose from oral starch, but not from oral glucose. These results suggest the preferential inhibition of the carbohydratedigesting enzymes. These seed shells have a series of heteropolyflavan-3-ols with doubly linked A-type linkages as well as single B-type bonds, and lack gallic acid esterification. ${ }^{71}$ Cocoa PA prevented the increase of blood glucose in genetically diabetic obese mice without affecting either body weight or total food consumption. ${ }^{81}$ When fed for 4 weeks, a procyanidin-rich chocolate prevented the unfavourable glucose response induced by the control polyphenol-free chocolate in a crossover study in volunteers. ${ }^{107}$

\section{Proteases}

Table 3 shows the inhibition of proteases by proanthocyanidins. A positive relationship between the degree of polyphenol polymerisation and the capacity of the polyphenols to inhibit porcine pancreatic elastase was observed. A molecular weight of at least 1154 Da was necessary to observe a significant inhibitory ability of the procyanidins. The kinetic parameters were also calculated, and these values confirmed that the inhibition is reversible and competitive. Molecular docking and dynamics simulations demonstrated that the tetramer structure has a higher affinity for the enzyme due the establishment of more contact points with the amino acids present in its active site. Hydrogen bond interactions and hydrophobic attraction established between the polyphenol groups and the side chain of residues stabilised and favoured the binding mode of this procyanidin. ${ }^{108}$ Gonçalves et al. (2011) showed that the interaction between procyanidin $\mathrm{B} 3$ and porcine pancreatic trypsin (PPT) strongly depends on the concentration of procyanidin used. Below the critical micellar concentration, the interaction is specific and most likely involves the establishment of hydrogen bonds between the hydroxyl groups of the polyphenol and the amide and carbonyl group of the protein backbone. In this concentration range, a significant

Table 3 Pancreatic Proteases inhibition activity by proanthocyanidins in in vitro experiments

\begin{tabular}{|c|c|c|c|c|c|c|}
\hline Source & $\begin{array}{l}\text { Main PAC } \\
\text { constituents }\end{array}$ & $\begin{array}{l}\text { Average } \\
\text { DP }\end{array}$ & $\begin{array}{l}\text { Linkage } \\
\text { type }\end{array}$ & $\begin{array}{l}\text { Trypsin } \\
\text { IC50 }\end{array}$ & $\begin{array}{l}\text { Elastase } \\
\text { IC50 }\end{array}$ & Ref. \\
\hline \multicolumn{6}{|l|}{$N$-benzoyl-DL-arginine- $p$-nitroanilide } & 192 \\
\hline F1 (mean $\left.M_{\mathrm{w}}: 950\right)$ & CA, EC \& gallates & $(3 \& 4)$ & & $2883 \mu \mathrm{M}$ & & \\
\hline F2 (mean $\left.M_{\mathrm{w}}: 1512\right)$ & & 5 & & $182 \mu \mathrm{M}$ & & \\
\hline F3 (mean $\left.M_{\mathrm{w}}: 2052\right)$ & & $(5-7)$ & & $118 \mu \mathrm{M}$ & & \\
\hline Vitis vinifera (grape seeds). & & 3 & $\mathrm{C} 2$ & & $5863 \mu \mathrm{M}$ & 108 \\
\hline \multirow[t]{2}{*}{ S: Suc-(Ala)3-p-nitroanilide } & & 4 & & & $585 \mu \mathrm{M}$ & \\
\hline & & $>4$ & & & $16 \mu \mathrm{M}$ & \\
\hline $\begin{array}{l}\text { Synthesis. S: } N \alpha \text {-Benzoyl-DL-arginine } \\
\text { 4-nitronalide hydrochloride }\end{array}$ & B3 & 2 & CA-( $(4 \beta-8)-\mathrm{CA}$ & $3914 \mu \mathrm{M}$ & & 109 \\
\hline
\end{tabular}


inhibition of PPT by procyanidin occurs. Above the critical micellar concentration, nonspecific interactions occur and the authors suggested that, in this case, the main driving force governing the interaction was hydrophobic, which is a much less specific binding process. It was also demonstrated that the carbohydrate pectin induces a dissociation of the tanninPPT complex. ${ }^{109}$

In conclusion the large amount of in vitro studies together with the few in vivo studies performed, shown that PA rich extracts inhibit digestive enzymes. One factor that may influence the effective inhibitory power observed in vitro is the metabolism of PA in the digestive system. However, because the site of action of PA on digestive enzymes is the small intestine lumen, PA bioavailability should not be a limiting factor. Several studies have shown that these compounds are stable in the stomach and small intestinal milieu and are expected to be present in the small intestinal lumen at relatively high concentrations following consumption of products with a high PA content. ${ }^{90}$ Furthermore, the reviewed bibliography shows that DP, type-A linkages, galloylation and diversity of monomers of PA increase the inhibition on digestive enzymes.

\section{Enteroendocrine regulation}

The importance of the brain-gut axis in the control of food intake is reflected in the dual role exhibited by many gut peptides as both hormones and neurotransmitters. The parasympathetic nerves innervating the stomach play an important role in digestion and absorption. It is generally understood that sympathetic excitation and parasympathetic inhibition affect feeding behaviour and also reduce food intake and body weight. ${ }^{110}$ Local effects such as the inhibition of gastric emptying might also contribute to decreases in energy intake, and activation of mechanoreceptors as a result of gastric distension may inhibit further food intake via neural reflex arcs. The circulating gut hormones have also been shown to act directly on neurons in hypothalamic and brainstem centres of appetite control. ${ }^{111}$ These hormones, with the exception of ghrelin, act to increase satiety and decrease food intake. There are only few studies examining the PA effects on the regulation of the neuropeptides and neurohormones of the central nervous system. Some PA-rich foods appear to have the potential to modulate the neuropeptides involved in food intake and satiety. Indeed, Massolt and colleagues demonstrated that the smell of chocolate could suppress appetite in humans. ${ }^{112}$ In their study, 12 females were given chocolate to eat and then randomised to either smell chocolate or to serve as a control (no eating or smelling). Eating and smelling chocolate both resulted in appetite suppression with no relationship observed between appetite levels and insulin, glucagon-like peptide-1 (GLP-1), or cholecystokinin levels. However, the smell of dark chocolate $(85 \%$ cocoa) resulted in a satiation response that was inversely correlated with the ghrelin levels. Because higher levels of ghrelin increase food intake, ${ }^{113}$ these findings suggest that regular cocoa and chocolate consumption may reduce appetite by decreasing ghrelin levels.
It is thought that Flavangenol extract, which contains oligomeric PA as a main constituent, might affect autonomic nerve activity. Tanida et al. showed that Flavangenol ingestion reduced body weight gain in rats fed a high-fat diet. These authors also showed that an acute intraduodenal injection of Flavangenol elevated the activity of the sympathetic nerve that innervates the brown adipose tissue (BAT) and inhibited the gastric vagal nerve activity in anesthetised rats. In addition, intra-oral injection of Flavangenol elevated the BAT temperature. These results thus suggest that Flavangenol supplementation exerts its body weight-reducing effects through changes in autonomic neurotransmission. ${ }^{110}$ If PA ingestion suppressed appetite, food intake should decrease. Pinent et al. (2015) have reviewed the effects of flavanols on the enteroendocrine system and the impact of these compounds on food intake. However, there are no conclusive results showing that PA suppresses food intake, once again because experiments addressing this subject are very scarce.

To study obesity experimentally, a cafeteria diet (CD) has frequently been used. The CD-treated rats display insulin resistance, increased insulin synthesis and secretion, and increased apoptosis in the pancreas. ${ }^{77}$ The CD also increases the insulin-degrading enzyme (IDE)-mediated insulin clearance capability. ${ }^{114}$ Furthermore, the CD caused ectopic lipid accumulation in the pancreas and modified the expression of key genes that control lipid metabolism. Chronic corrective treatment using GSPE ameliorates insulin resistance in CD model. ${ }^{78}$ The effects of this extract might be partially explained by its insulin-like effect on insulin-sensitive cell lines, ${ }^{115}$ as well as through its effects on pancreatic $\beta$-cell function and by preventing the effects of the CD on insulin secretion and production and lipid accumulation in the pancreas. ${ }^{116}$ The antihyperglycaemic effect of GSPE may be partially due to the insulinomimetic activity of the procyanidins as shown using insulin-sensitive cell lines. GSPE stimulated glucose uptake in L6E9 myotubes and 3T3-L1 adipocytes in a dose-dependent manner. Similar to the action of insulin, the effect of GSPE on glucose uptake was sensitive to wortmannin, an inhibitor of phosphoinositol 3-kinase and to SB203580, an inhibitor of p38MAPK. GSPE exposure also stimulated translocation of the glucose transporter-4 (GLUT-4) to the plasma membrane. ${ }^{115}$ GSPE also stimulated glycogen and lipid synthesis in 3T3-L1 cells, although less effectively than insulin. ${ }^{117}$ However, GSPE uses mechanisms complementary to those of the insulin signalling pathways to bring about these effects. ${ }^{117}$ GSPE is able to modulate the apoptosis and proliferation of the INS-1E pancreatic beta-cell line under altered conditions (such as high glucose, insulin and palmitate), but not under basal conditions. ${ }^{118}$ In summary, PA have insulin-like effects in insulinsensitive cells that could help to explain their anti-hyperglycaemic effects in vivo (Table 4).

Moreover, the chronic treatment of healthy rats with GSPE increases the insulin/glucose ratio after oral glucose administration more than that after intraperitoneal glucose infusion, suggesting an incretin-like effect. ${ }^{119}$ The cafeteria diet decreased the active GLP-1 plasma levels, which was attributed 
to a decreased intestinal GLP-1 production linked to reduced colonic enteroendocrine cell populations. These effects were prevented by GSPE. A dose of $25 \mathrm{mg} \mathrm{kg}^{-1}$ bw of the same extract for 12 weeks prevented the cafeteria diet-induced decrease in the numbers of colonic GLP-1-producing cells. Similarly, the acute administration of a dose of $10 \mu \mathrm{g} \mathrm{kg}{ }^{-1} \mathrm{bw}$ of the procyanidin tetramer cinnamtannin A2 to fasted mice also increases the plasma levels of active GLP-1. ${ }^{120}$ GSPE also increased the hypothalamic GLP-1 production and downregulated GLP-1R, opposing the effects of the cafeteria diet. ${ }^{121}$ The gut-derived hormone GLP-1 is released in response to glucose ingestion and enhances insulin secretion by the pancreas. Intestinal dipeptidyl-peptidase 4 (DPP4) is present at the site of incretin production, and therefore cleaves these molecules almost immediately after their secretion. Preventing the degradation of endogenous incretin hormones by inhibiting DPP4 has therefore emerged as a strategy for the control of glucose homeostasis. In vitro inhibition assays showed that GSPE inhibits pure DPP4. Chronic GSPE treatment of human intestinal cells (Caco-2) caused a decrease in DPP4 activity and gene expression. GSPE were also assayed in vivo. Intestinal, but not plasma, DPP4 activity and gene expression were decreased by GSPE in healthy and diet-induced obese animals. In genetically obese rats, only the DPP4 gene expression was downregulated. Thus, inhibition of the intestinal DPP4 activity by the procyanidins, either directly and/or via downregulation of gene expression, could be responsible for some of their effects on glucose homeostasis. ${ }^{119}$

In summary, one study in humans showed effects of PA rich food on appetite suppression. On the other hand, animal studies with PA rich extracts showed effects in endocrine signals affecting glucose homeostasis. However, the results on appetite and satiety are quite inconclusive because usually the experiments are not designed to address these items.

Table 4 Proanthocyanidins promoting glucose metabolism

\begin{tabular}{lll}
\hline Experimental model & Main effects & Proposed mechanism of action \\
\hline $\begin{array}{l}\text { 3T3-L1 cells + 140 } \mathrm{mg} \mathrm{L}^{-1} \text { GSPE for } \\
1 \mathrm{~h}\end{array}$ & $\begin{array}{l}\text { Stimulation of glucose uptake and of glycogen } \\
\text { and lipid synthesis }\end{array}$ & $\begin{array}{l}\text { Activation of insulin receptor, activation of Akt, } \\
\text { p44/42 and p38 MAPKs signaling pathways, } \\
\text { translocation of Glut-4 to the plasma } \\
\text { membrane }\end{array}$
\end{tabular}

3T3-L1 cells $+140 \mathrm{mg} \mathrm{L}^{-1}$ GSPE for $15 \mathrm{~h}$

3T3-L1 with insulin resistance induced by different agents +

$100 \mathrm{mg} \mathrm{L}^{-1} \mathrm{GSPE}$

Male Zucker rats fed with medium

fat diet + $20 \mathrm{mg}$ GSPE $\mathrm{kg}^{-1}$ bw for 19 weeks

Female Wistar rats fed with medium

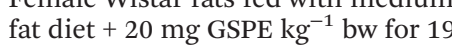
weeks

Male HFD-hamsters $+20 \mathrm{mg} \mathrm{kg}^{-1}$

bw for 12 weeks

Female Hyperinsulinemic CD-rats +

$25 \mathrm{mg} \mathrm{kg}^{-1}$ bw for 30 days

Female healthy rat $+25 \mathrm{mg}$ GSPE

$\mathrm{kg}^{-1}$ bw for 19 days + oral glucose administration

Female CD-rats + $25 \mathrm{mg} \mathrm{GSPE} \mathrm{kg}{ }^{-1}$ bw for 12 weeks

Female Zucker fa/fa rats $+35 \mathrm{mg}$ GSPE $\mathrm{kg}^{-1}$ bw for two months

INS-1E pancreatic $\beta$-cells $+25 \mathrm{mg} \mathrm{L}{ }^{-1}$ GSPE for 24 hours

Female Wistar rats, different GSPE doses and periods of time

INS-1E pancreatic $\beta$-cells incubated under different stress conditions +1 , 5-25 $\mathrm{mg} \mathrm{L}^{-1}$ of GSPE

Female Wistar CD-rats $+25 \mathrm{mg} \mathrm{kg}^{-1}$ bw for 30 days

Male Wistar CD-rats $+25 \mathrm{mg}$ per kg for 21 days

Pancreatic islets isolated from rats + $25 \mathrm{mg}$ GSPE per $\mathrm{kg}$ for 45 days
Stimulation of glucose uptake, glycogen synthesis and triglyceride turnover Stimulation of glucose uptake

Modulation of Glut4 activation

Improvement of glycemia and adiponectinemia

Decrease of insulinemia

Reduction of hyperglycemia

Reduction of plasma insulin, improvement of HOMA index

Increase insulin/glucose ratio

Downregulation of Pparg2, Glut4 and Irs1 in mesenteric WAT

Incretin like effect, DPP4 inhibition

Correction of HOMA-IR at week 9 and increase in colonic active GLP-1.

No effects on plasma glucose or insulin. Modulation of the proteome of pancreatic islets: limitation of insulin synthesis and secretion, and modulation of apoptotic factors Reduced basal and glucose-stimulated insulin secretion

Low doses increased insulinemia, high doses decreased insulinemia

Reduction of lipid accumulation, proapoptotic and antiproliferative effects Decrease of plasma C-peptide and insulin. Reduction of insulin production and TG content in the pancreas and in $\beta$-cells Improvement of insulin resistance. Modulation of pro- and anti-apoptotic markers in the pancreas
Prevention of enteroendocrine cell loss

Differential expression of hexose metabolic processes, response to hormone stimulus and apoptosis and cell death

Alteration of the cellular membrane potential

Modulation of insulin production and insulin degradation (through changes in insulindegrading enzyme mRNA), reduction of pancreatic islets responsiveness to glucose

Lower insulin and Pdx1 mRNAs in pancreas. Up-regulation of Cpt1a; downregulation of Fasn and Srebf1 and increase of AMPK in pancreas Prevention of the increase in insulin mRNA levels and triglyceride accumulation induced by cafeteria, increase of Bax protein levels Alteration of miR-1249, miR-483, miR-30c-1, and miR-3544 expression 


\section{Energy storage regulation}

\section{Adipose hyperplasia and hypertrophy}

In obesity, hypertrophic adipocytes trigger adipose tissue hyperplasia, and the increases in both adipocyte size and number are driven by a positive energy balance. Hypertrophy of the adipose cells is largely related to the triglyceride mass, which is determined by the rate of lipid synthesis and degradation, both of which are regulated by PA. ${ }^{122}$ Recently, it has been shown that Oligonol, a product from lychee containing monomers and PA, causes significantly increased lipolysis in primary adipocytes. This effect is independent of cAMP production, but depends on the activation of the ERK1/2 pathway. ${ }^{123}$ Lastly, the activation of both $\beta$-oxidation and glycerolipid/free fatty acid cycle by GSPE has been proposed as a mechanism by which supplementation with this extract contributes to decreasing both the plasma FFA levels and lipid accumulation in adipose tissue. ${ }^{66}$ With regard to hyperplasia, changes in adipocyte number are governed by changes in preadipocyte maturation by adipogenesis, preadipocyte replication and adipocyte apoptosis. $^{122}$ To understand the mechanisms that reduce fat mass, studies of substances that decrease preadipocyte differentiation and proliferation have been performed. Colitti and Grasso (2014) have extensively reviewed the regulation of adipocyte life by natural products, but the effects of PA were not included in this review. ${ }^{124}$ With regard to PA, it has been shown that GSPE inhibits the differentiation of 3T3-L1 preadipocytes to mature adipocytes when added at the onset of differentiation. The modulation of cell cycle-related genes by PA suggest that these compounds interfere with the process of preadipocyte proliferation. ${ }^{125}$ Furthermore, a PA-enriched fraction from Vaccinium floribundum significantly increased Pref-1 expression in preadipocytes. ${ }^{126}$ However, the inhibition of adipogenesis, which results in a lower fat accumulation in adipocytes, could lead in vivo to the ectopic deposition of excess lipid in nonadipose organs, causing insulin resistance and lipotoxicity. ${ }^{124}$ Thus, adipose tissue should not be considered intrinsically bad. Moreover, a new cell type was recently identified, the "brite" or "beige" adipocyte that presents a unique gene expression profile of compared to both brown and white adipocytes. Brite adipocytes can be found dispersed through the white fat depots both in rodents and humans, forming a multidepot organ with plastic properties. ${ }^{127,128}$ Consistent with this plasticity, some bioactive compounds have been shown to be associated with the browning of WAT (reviewed by Bonet et al.). ${ }^{129}$ The induction of the browning of white fat by PA opens a new research field for these flavonoids as a potential strategy for the management of obesity and related diseases.

\section{Glucose metabolism}

Several clinical studies in humans have been performed to assess the potential anti-hyperglycaemic effect of dietary PA using PA-rich foods or extracts (reviewed by Pinent et al., 2012). ${ }^{130}$ For instance, some studies have reported that consumption of flavan-3-ols is inversely associated with the risk of developing type 2 diabetes (T2D) ${ }^{131,132}$ and that the chronic consumption of Pycnogenol ${ }^{\circledR}$, muscadine grape products, chocolate or green tea PA improve glycaemic control in T2DM subjects. ${ }^{133-137}$ However, other studies did not show significant changes in glucose and/or insulin levels after dietary supplementation with a flavanol-rich cacao drink or a polyphenolrich chocolate in T2DM subjects. ${ }^{138,139}$ These discrepancies could have been due to the PA levels administered in each study.

Similarly, studies using animal models have produced controversial results regarding the anti-hyperglycaemic activity of PA (reviewed by Pinent et al., 2012 115 and González-Abuín et al., $2015^{140}$ ). One explanation is that the anti-hyperglycaemic activity of PA is dependent on the hyperglycaemic animal model, PA dose, length of treatment and whether the PA are administered before or after hyperglycaemia induction. For instance, a dose of $25 \mathrm{mg}$ of GSPE per $\mathrm{kg}$ of body weight improves the glycaemic state and insulin resistance when is administered for 21 or 30 days, but not if given for a shorter period of time (10 days), ${ }^{78,141}$ in an high fat diet (HFD) rat model. Furthermore, higher doses of GSPE (50 $\left.\mathrm{mg} \mathrm{kg}^{-1} \mathrm{bw}\right)$ were also ineffective in improving insulin resistance, using the same animal model. ${ }^{78}$

The anti-hyperglycaemic effect of PA seems to be mediated by mimicking insulin action on the liver and peripheral tissues and/or by affecting insulin secretion through the modulation of pancreatic $\beta$-cell functionality and the incretin system (Table 4).

The best studied mechanism by which PA induces the antihyperglycaemic effect is by the stimulation of glucose uptake into insulin-sensitive tissues, thus mimicking insulin effects. In vitro studies have demonstrated that PA increase glucose uptake in hepatocytes, ${ }^{142-145}$ adipocytes, ${ }^{115,143}$ and myotubes. ${ }^{115,143,146}$ Furthermore, PA up-regulate the expression of GLUT-4 in adipose tissue and muscle in vivo ${ }^{115,146-148}$ and modulate GLUT-4 translocation to the plasma membrane. ${ }^{149,150}$ These studies strongly suggest the involvement of $\mathrm{AMPK}^{78,145,146,148,151}$ and $\mathrm{AKT}^{149,150}$ on the molecular mechanisms by which PA induce glucose uptake (Table 6).

The liver plays a central role in maintaining glycaemia because this organ can supply glucose when its plasma levels are low. However, excessive glucose production by the liver is linked to hyperglycaemia. Interestingly, PA targets hepatic glycolytic and gluconeogenic enzymes such that PA repress gluconeogenesis, ${ }^{142,146,151-153}$ thus reducing glucose production by the liver.

In conclusion, there are controversial results both in humans and in animal models. In humans it could have been due to the PA levels administered in each study, probably because high quantities of PA are needed to improve glycaemia in humans. In animal models, it seems that anti-hyperglycaemic activity of PA is severely affected by the experimental conditions used.

\section{Lipid metabolism}

Several epidemiological studies have focused on the effects of PA on dyslipidaemia, but the results have been inconsistent. A 
meta-analysis of nine trials that evaluated the effect of PA extracts showed no statistically significant effect on total cholesterol (TC), triglycerides (TG), LDL cholesterol (LDL-C), or HDL cholesterol (HDL-C) levels. ${ }^{154}$ However, other studies showed that PA significantly decreases TC and LDL-C. ${ }^{155}$ Several differences, such as a low sample size with a low power to detect differences, different extracts, doses of PA and weeks of treatment as well as the clinical condition of the population studied could account for these discrepancies among the studies. Therefore, more studies are necessary to clarify the authentic effects of PA on plasma lipids in humans.

Unlike the human studies, many studies using animal models have shown a hypolipidaemic effect of PA. ${ }^{156}$ An acute dose of GSPE reduces plasma TGs, apo B and LDL-C levels in healthy rats. ${ }^{157,158}$ Additionally, chronic treatment with GSPE corrects the dyslipidaemia, primarily the TG levels, associated with a high-fat diet in rats ${ }^{24,159,160}$ and hamsters. ${ }^{66}$ Chronic treatment with GSPE also reduces the hepatic steatosis induced by a high-fat diet. ${ }^{159,160}$

The hypotriglyceridaemic effect of PA has been extensively studied. The levels of the TG-rich lipoproteins, chylomicrons (CM) and very low-density lipoproteins (VLDL) depend on the secretion of these lipoprotein complexes by the intestine and the liver and on their catabolism by the lipoprotein lipase
(LPL) in extra-hepatic tissues. Interestingly, GSPE represses the secretion of VLDL-TG ${ }^{158}$ and $\mathrm{CM}^{-\mathrm{TG}^{161}}{ }^{16}$ without affecting LPL activity or expression in WAT and muscle. ${ }^{158}$ Therefore, it is possible that the PA reduce plasma TG by repressing lipoprotein secretion and not by affecting its catabolism. Impaired lipid availability in enterocytes seems to be the primary mechanism for the PA-induced reduction of CM secretion. In this context, PA increase the faecal excretion of cholesterol in rats $^{162}$ and inhibit the activity of pancreatic lipase in vitro, ${ }^{163}$ indicating reduced lipid absorption. Moreover, GSPE represses the expression of long chain acyl-CoA synthetases (ACSL)-5 and -3 , which supply fatty acids for TG synthesis in enterocytes (Table 5).

The repression of VLDL secretion has also an important role in the hypotriglyceridaemic action of PA. Similar to the observations in the intestine, impaired lipid availability in hepatocytes seems to be the main contributor to reduced hepatic VLDL. In this context, GSPE inhibits de novo synthesis of TGs and cholesterol, as well as their secretion, in the hepatic cell line HepG2. ${ }^{164}$ Moreover, carnitine palmitoyltransferase I (CPT1) is overexpressed in the livers of rats treated with an acute dose of GSPE. ${ }^{158}$ Together, these results suggest that PA targets fatty acids to oxidation instead of to TG synthesis. Moreover, acute administration of GSPE represses the

Table 5 Proanthocyanidins promoting lipid metabolism

\begin{tabular}{ll}
\hline Experimental model & Main effects \\
\hline $\begin{array}{l}\text { Male Wistar rats + a single dose (250 mg } \\
\text { GSPE kg }\end{array}$ & $\begin{array}{l}\text { Reduction of plasma TG, apo B, LDL-C. In the } \\
\text { liver, levels of total lipids, TG, TC, free } \\
\text { cholesterol, and esterified cholesterol were not } \\
\text { h. }\end{array}$ \\
$\begin{array}{l}\text { HepGected by GSPE } \\
\text { Specific siRNA + 50 mg L }\end{array}$ \\
$\begin{array}{l}\text { SHP-null mousetion of ApoB and TG synthesis and } \\
\text { GSPE kg } \mathrm{kg}^{-1} \text { ) }\end{array}$
\end{tabular}

Abolition of the hypotriglyceridemic effect of

GSPE reduced triglyceridemia in in wild type mice but not in FXR-null mice

Increased lipolysis

Normalization of plasma TG and LDLcholesterol, which were increased with the HFD. Reduction of hepatic lipogenesis

Lower TG secretion only in the fasting state Caco 2 cells in post-prandial and
states + of $25-100 \mathrm{mg} \mathrm{L}^{-1} \mathrm{GSPE}$

Male Wistar rats fasted for $14 \mathrm{~h}$, orally loaded with lard + $250 \mathrm{mg}$ GSPE $\mathrm{kg}^{-1}$ bw

Male HFD-hamster $+25 \mathrm{mg}$ GSPE kg ${ }^{-1}$ bw for 15 days

FAO cells + $25 \mathrm{mg} \mathrm{GSPE} \mathrm{L}{ }^{-1}$

Male healthy and hiperlipidaemic Wistar rats + $25 \mathrm{mg}$ GSPE $\mathrm{kg}^{-1}$ induced by lard oil ingestion

Increased cholesterol
lipogenesis in liver

Correction of dyslipidaemia and hepatic steatosis GSPE by the $\mathrm{SHP}^{-/-}$genotype

Proposed mechanism of action

Ref.

Induction of liver CYP7A1 and SHP

157

expression. Increase of cholesterol reverse

transport and of its elimination via bile acids

Modulation of SHP expression in HepG2 cells. Modulation of hepatic expression of genes related to lipid, fatty acid, and steroid metabolism in wild-type but not in $\mathrm{SHP}^{-/-}$ mice

Activation of FXR, transient upregulation of

SHP expression and subsequent downregulation of SREBP1 expression Activation of ERK1/2 pathway

Repression of key regulators of lipogenesis and (VLDL) assembling: SREBP1, MTP and DGAT2, which were overexpressed by the HFD, in liver

Repression of the expression of long chain acyl-CoA synthetases: (ACSL) 5 in the postprandial state and ACSL3, ACSL5 in the fasting state

Repression of both chylomicron-TG and VLDL-TG secretion

Activation of both, glycerolipid/FFA cycle and $\beta$-oxidation in WAT

Increase of ATP-binding cassette A1 mRNA and protein levels, and decrease of fatty acid synthase mRNA and protein levels by repression of miR-33 and miR-122

Repression of miR-33, miR-122 
expression of 3-hydroxy-3-methyl-glutaryl-CoA reductase ${ }^{164}$ (the rate-limiting enzyme in the cholesterol biosynthetic pathway), phosphatidic acid phosphatase ${ }^{164,165}$ (the enzyme that generates diglycerides from phosphatidic acid for TG synthesis) and diacylglycerol acyl transferase $2^{24}$ (the enzyme that catalyses the last reaction of TG synthesis). A proteomic study also confirmed that chronic consumption of GSPE represses fatty acid and triglyceride synthesis in rats fed a high fat diet. ${ }^{147}$

PA also improve lipid homeostasis by increasing the reverse transport of cholesterol to the liver and its elimination via bile acids. In this context, GSPE causes the overexpression of the ATP-binding cassette transporter ABCA1, a crucial factor for HDL lipidation, in the livers of healthy and hiperlipidaemic rats as well as in peripheral blood mononuclear cells. Moreover, acute treatment with GSPE induces the overexpression of CYP7A1, ${ }^{157}$ the enzyme that controls bile acid synthesis (Table 5).

The molecular mechanism by which GSPE modulates lipid metabolism has been studied in the liver and includes nuclear receptors and microRNAs. The first mechanism described involves the activation of the nuclear receptor farnesoid $\mathrm{X}$ receptor (FXR), upregulation of the nuclear receptor small heterodimer partner (SHP) and the subsequent repression of the transcription factor sterol-regulatory element binding protein-1 (SREBP-1) in liver. ${ }^{164,165}$ Recently, miRNAs have been emerged as a new molecular mechanism by which PA and other polyphenols could modulate metabolism. ${ }^{166,167}$ Specifically, miR-33 and miR-122, two miRNAs that are key controllers of lipid metabolism, have been suggested to be involved on the hypolipidaemic effect of PA because they are repressed by GSPE in different animal models. ${ }^{159,168}$

The results obtained with PA in animals should be used to plan better experiments addressed to study the PA actions on lipid metabolism in humans.

\section{Energy expenditure regulation}

An increase in energy expenditure (EE) is one method to combat obesity. PAs regulate EE by different mechanism and acting in various tissues, the most studied of which are adipose tissue, skeletal muscle and liver. Mammalian BAT is a key tissue in EE because it can establish non-shivering thermogenesis through dissipation of excess energy as heat by specifically activating mitochondrial uncoupling protein 1 (UCP1). Thus, one protective strategy against obesity could be increasing the number and activity of BAT cells. ${ }^{169-171}$ Specifically, natural compounds that mimic the activity of the nervous system and increase thermogenesis offer a therapeutic potential and provide a rational approach to obesity treatment. ${ }^{172}$ Indeed, as mentioned above, the decrease in body weight gain due to consumption of black soybean seed coat extract was attributed to the upregulation of UCP2 and UCP1 in WAT and BAT, respectively, thus enhancing EE. ${ }^{173}$ Chronic administration of GSPE to HFD-obese rats tends to correct the obesityinduced decreases in the expression of the BAT Sirtuin 1
(Sirt1) and Peroxisome proliferator-activated receptor gamma coactivator 1-alpha (PGC1- $\alpha$ ) genes. These data suggest a GSPE-induced improvement in the BAT thermogenic capacity of the obese rats. Interestingly, increases in the gene expression and protein content of UCP1 as well as an enhancement of BAT mitochondrial respiration were also observed. These rats showed a decreased body weight gain. ${ }^{74}$ When GSPE was administered with lard oil to fasted Wistar rats, the BAT activity and mitochondrial function were improved in the postprandial period. ${ }^{171}$ Likewise, Flavangenol has been shown to increase the mRNA levels of fatty acid oxidative enzymes such as PGC1- $\alpha$, acyl-CoA oxidase, and CPT in an in vitro model of fatty liver. Moreover, Flavangenol suppressed intracellular fat accumulation, suggesting that the molecular mechanism involves the induction of fatty acid oxidation (Table 6). This effect was mainly attributed to procyanidin B1. ${ }^{174}$

AMP-activated protein kinase (AMPK) is a key regulator of energy metabolism. In C57BL/6 mice fed a HFD, supplementation with cacao beans was shown to activate AMPKo in the skeletal muscle, liver and adipose tissue. In this study, the cacao bean supplementation suppressed the HFD-induced fat deposition in WAT without affecting food intake. Furthermore, the increased expression of UCP1 in BAT, UCP2 in WAT and UCP3 in skeletal muscle was proposed as an underlying mechanism, due to the involvement of UCPs on thermogenesis and energy metabolism. Furthermore, the cacao bean supplementation tended to cause upregulation of PGC1- $\alpha$ with a pattern similar to those of the UCPs. The authors indicated that the cacao beans prevent obesity by up-regulating the expression levels of UCPs and PGC1- $\alpha$ through the action of AMPK, thus preventing obesity by increasing $\mathrm{EE}$, which resulted in the reduction of the WAT weight. ${ }^{148}$ Moreover, the cacao bean supplementation also increases the levels of adiponectin secreted by the WAT, and this effect could be involved at least in part on the AMPK $\alpha$ activation. The feeding of male C57BL6 mice with a tea-based beverage rich in polyphenols results in changes in the respiratory complexes of the mitochondria in the skeletal muscle. The authors attributed these changes to an increase in AMPK- $\alpha$ and suggested that a dose-dependent reduction in energy availability was associated with the decrease in the adipose tissue weight and a slight but significant increase in the plasma NEFA concentrations. The proposed decrease in energy availability was confirmed by the observations that systemic absorption of carbohydrates decreased, and insulin sensitivity was reduced. Taken together, these results suggest that the effects of the green tea polyphenols may be related to their ability to modulate energy uptake leading to mitochondrial adaptations. ${ }^{175}$ The administration of PA from cocoa powder to healthy mice also reduced the resting EE. Moreover, key enzymes of $\beta$-oxidation were induced in gastrocnemius and soleus muscles, while the mitochondria copy numbers increased in these muscles and in BAT. These results imply that PA enhance lipolysis and promote mitochondrial biogenesis in the muscles. ${ }^{176}$ The administration of the anti-obesity agent, acacia-rich tannin extract, to mice increased the mRNA and protein expression of UCP3 and of the $\beta$-oxidation 
Table 6 Proanthocyanidins promoting energy expenditure metabolism

Experimental model
Male Wistar rats + Intra-duodenal and
intra-oral injections ( $3 \mathrm{mg}$ flavangenol/
$2 \mathrm{~mL}$ ).
Male HFD-hamster + GSPE. The amount
of GSPE corresponded to $2.5 \mathrm{~g}$ day ${ }^{-1}$ for
a $70 \mathrm{~kg}$ human.

Male HFD-obese diabetic KKAy mice + acacia extract $2.5 \%(\mathrm{w} / \mathrm{w})$ or $5.0 \%(\mathrm{w} / \mathrm{w})$ for 7 weeks

Male HFD-C57BL/6 mice + Black soybean extract $0.2 \%-2 \%(\mathrm{w} / \mathrm{w})$ for 14 weeks

Male Wistar rats + acute oral gavage with $250 \mathrm{mg} \mathrm{GSPE} \mathrm{kg}^{-1}$ bw in lard oil

Female Zucker fa/fa rats + 35 mg GSPE per $\mathrm{kg}$ for 68 days

Male Western-diet fed TSOD-mice $+3 \%$ or $5 \%$ flavangenol. HepG 2 cells + $0.5 \mathrm{mM}$ palmitic acid $+(10,20$ and $30 \mu \mathrm{g} \mathrm{mL}^{-1}$ )

Male HFD-C57BL/ 6 mice $+0.5 \%$ or $2 \%$ cacao liquor PA for 13 weeks

Male C57BL6 mice had unlimited access to a tea based beverage for 3 months

Male C57BL/J mice + $50 \mathrm{mg}$ per $\mathrm{kg}$ Cocoa fraction for 2 weeks

Male Wistar rats + acute oral gavage

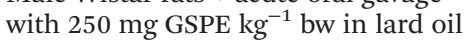

Male Wistar CD-rat + $25 \mathrm{mg}$ GSPE per $\mathrm{kg}$ for 21 days
Main effects

Elevated BAT temperature. Elevated BAT sympathetic nerve activity; suppressed vagal activity

Reduction of insulinemia and leptinemia. Increasing of adiponectin level. Lowered glycemia and HOMA-IR. Prevention of cardiac production of superoxide and $\mathrm{NAD}(\mathrm{P}) \mathrm{H}$ oxidase expression

Suppression of increases in plasma glucose and insulin. Higher mRNA and protein expression of CPT1, ACO and UCP3 in muscle. Under expression of SREBP-1c, ACC and FAS in liver. Increased mRNA expression of adiponectin in WAT

Suppression of fat accumulation in mesenteric adipose tissue, reduction of the plasma glucose level, and enhancement of insulin sensitivity Lower plasma TG, FFA, glycerol and urea levels. In muscle, lower FATP1 mRNA levels and higher mitochondrial oxygen consumption.

Overexpression of UCP1 and PGC1- $\alpha$, and modulated activity of enzymes, involved in the citric acid cycle and electron transport chain in BAT.

Enhanced ability to oxidize pyruvate, and increased activity of enzymes involved in oxidative phosphorylation in muscle mitochondria

Suppression of intrahepatic fat accumulation. Increase of mRNA levels of fatty acid oxidative enzymes (PPAR $\alpha$, acyl-CoA oxidase, CPT).

Suppression of intracellular fat accumulation in HepG2 cells

Suppression of postprandial and chronic hyperglycemia, glucose intolerance and fat accumulation in WAT. Secretion of adiponectin from WAT. AMPK $\alpha$ activation in muscle, liver and WAT. Muscle GLUT4 translocation. Overexpression of UCP1 in BAT and UCP3 in muscle

Decrease of intestinal and systemic absorption of carbohydrates together with an inhibition of insulin sensitivity. Skeletal muscle

mitochondrial changes of respiratory complexes and increase of AMPK $\alpha$ levels

Increase of CPT2 in skeletal muscle. Increase of UCP1 in BAT. Increase of the mitochondria copy number in gastrocnemius and soleus muscles and BAT. Reduced resting EE Lower plasma TG, NEFA, TC levels. Lower Ppar$\alpha$, Pgc1- $\alpha$, Mnsod mRNAs in muscle. Lower muscle ROS production and plasma creatin kinase. Higher COX activity and increased Pgc1$\alpha$, Srebpc mRNAs in WAT

Lower RQ. Higher plasma adiponectin. Reduction of insulin resistance. Up-regulation of muscle Cd36, Lpl and Cpt1b gene expression Higher mitochondrial functionality and oxidative capacity in muscle. Increase of AMPK $\alpha$ phosphorylation
Proposed mechanism of action

Ref.

Autonomic neurotransmission regulation

110

Modulation by adiponectin

Increased expression of EE-related genes in skeletal muscle, and decreased fatty acid synthesis and fat intake in liver

UCP1 and UCP2 upregulation in BAT and 173 in WAT

Increased thermogenesis. Increased muscle and BAT mitochondrial function

Stimulation of mitochondrial function in skeletal muscle

Induction of fatty acid oxidation

Activation of AMPKa, promotes GLUT4 translocation and induces the expression of UCPs and PGC-1a.

Mitochondrial adaptations trough AMPKo activation

Promotion of mitochondrial biogenesis and enhancement of lipolysis.

Activation of mitochondrial biogenesis and lipogenesis in WAT.

Activation of muscle $\beta$-oxidation through 75 which controls the expression of these enzymes. The acacia polyphenols also decreased the expression of PPAR $\gamma^{179}$ and lipoprotein lipase (LPL) ${ }^{180}$ mRNAs. Together, these results indicate that the liver may suppress the onset of obesity and fatty liver by increasing the expression of EE-related genes in the skeletal muscles and liver and by decreasing the fatty acid 
synthesis and fat uptake in the liver. ${ }^{72}$ The administration of an acute dose of GSPE with lard activates mitochondria biogenesis and lipid accumulation and oxidation in adipose tissue in the postprandial period, ${ }^{181}$ which would protect the organism against fatty acid leakage from the adipocytes. At the same time, GSPE prevents muscle damage and reactive oxygen species (ROS) production. ${ }^{181}$

The chronic administration of GSPE to CD-fed rats increases AMPK phosphorylation in the skeletal muscle, consistent with the observation of high plasma adiponectin levels. Moreover, there was a significant overexpression of LPL, cluster differentiation 36 (Cd36), CPTIb genes, and higher ATPase activity in skeletal muscle, concomitant with the reduced TG levels in plasma. These outcomes are consistent with a role for GSPE in redirecting circulating TG to skeletal muscle for fat oxidation and ATP synthesis. ${ }^{181}$ In addition, GSPE improved the fat content of the liver. ${ }^{24}$ All of these changes are consistent with the high circulating adiponectin levels because it has been reported that adiponectin increases the expression of molecules involved in fatty acid transport (CD36) and combustion (acyl-coenzyme A oxidase) in skeletal muscle. ${ }^{182}$ Thus, chronic administration of GSPE to CD-fed rats ameliorated the unbalances associated with obesity by altering the regulation of lipid metabolism, secondary to AMPK action (Table 6). GSPE also modifies energy metabolism in the muscles of Zucker obese rats, specifically by increasing the capacity to oxidise pyruvate while contributing to a reduction in muscle ROS generation. ${ }^{183}$ Another study, in this case performed in hamsters, of a chronic administration of GSPE concomitant with a high fat diet, revealed that GSPE increases adiponectin levels, thus improving the adipokine levels associated with the high fat diet, and thus modulating the obesity-related energy imbalance. ${ }^{184}$

Few studies have reported the relevance and potential of grape seed proanthocyanidins in the treatment of obesity in humans. In one randomised, placebo-controlled, double-bind, cross-over study, subjects who received $300 \mathrm{mg}$ of grape-seed extract supplement with more than $90 \%$ of PA showed no difference in $24 \mathrm{~h}$ energy intake compared with the placebo. Only in those subjects whose energy requirements were lower than the median was there an effect: these subjects had a decrease of $4 \%$ in their $24 \mathrm{~h}$ energy intake compared to the placebo. ${ }^{185}$ In another study, overweight and obese subjects who consumed an isocaloric diet with $10 \%$ of energy from white wine or grape juice showed significantly reduced body weights, although there was no placebo group in this study. ${ }^{186}$

In summary, PA extracts seem to contribute to obesity improvement by changing body energy partitioning, preventing in this way the energy imbalance associated to obesity.

\section{Conclusion}

One proposed limitation of proanthocyanidins is their low systemic bioavailability. PA oligomers larger than trimers have not been detected in plasma following the consumption of PA- rich products. However, it is not necessary that PA be absorbed to exert their actions. It has been demonstrated that PA inhibit digestive enzymes and as a consequence of the inhibition of lipase and amylase, fat and glucose absorption from the gut were repressed. Factors that positively affect inhibition are: the degree of polymerisation, the percentage of high type A-linkages, the percentage of galloylation and the diversity of monomers in the PA composition. It should be noted that other phytochemicals present in the extract, although minor, may also participate in the effects described. Furthermore, microbial catabolic activity could change and consequently could affect the bioavailability and activity of these compounds. Other effects of PA in the gut include an incretin-like function and regulation of gastrointestinal tract-brain signals, although more studies are needed to address whether PA truly control satiety and food intake. However, beyond the effects on the suppression of food intake, the anti-obesity effects of PA appear to be more attributable to increased energy expenditure. Thus, PA cause the upregulation of EE-related genes in skeletal muscle and liver, while fatty acid synthesis and fat uptake in the liver are decreased. In addition to reducing obesity, PA also reduce hyperinsulinaemia by increasing adiponectin secretion by white adipocytes and elevating the expression of GLUT4 in skeletal muscle. There are discrepancies in the literature regarding the effects of PA on fat and body weights; in a number of experiments PA have caused decreases in body weight gain while in other experiments no effects have been observed. Importantly, even in cases in which neither fat mass nor body weight were affected, the metabolic inflexibility of the obese subjects was improved by PA uptake. Specifically, fatty acid oxidation was increased and insulin responses were improved, implying AMPK activation.

\section{Acknowledgements}

This study was supported by grant number AGL2013-40707-R from the Ministerio de Economía y Competitividad of the Spanish Government.

\section{References}

1 WHO, Fact sheet $N^{\circ} 311,2014$.

2 J. Erdmann, B. Kallabis, U. Oppel, O. Sypchenko, S. Wagenpfeil and V. Schusdziarra, Am. J. Physiol.: Endocrinol. Metab., 2008, 294, E568-E575.

3 S. Klein, L. E. Burke, G. a. Bray, S. Blair, D. B. Allison, X. Pi-Sunyer, Y. Hong and R. H. Eckel, Circulation, 2004, 110, 2952-2967.

4 M. Ng, T. Fleming, M. Robinson, B. Thomson, N. Graetz, C. Margono, E. C. Mullany, S. Biryukov, C. Abbafati, S. F. Abera, J. P. Abraham, N. M. E. Abu-Rmeileh, T. Achoki, F. S. AlBuhairan, Z. A. Alemu, R. Alfonso, M. K. Ali, R. Ali, N. A. Guzman, W. Ammar, P. Anwari, A. Banerjee, S. Barquera, S. Basu, D. A. Bennett, Z. Bhutta, 
J. Blore, N. Cabral, I. C. Nonato, J.-C. Chang, R. Chowdhury, K. J. Courville, M. H. Criqui, D. K. Cundiff, K. C. Dabhadkar, L. Dandona, A. Davis, A. Dayama, S. D. Dharmaratne, E. L. Ding, A. M. Durrani, A. Esteghamati, F. Farzadfar, D. F. J. Fay, V. L. Feigin, A. Flaxman, M. H. Forouzanfar, A. Goto, M. A. Green, R. Gupta, N. Hafezi-Nejad, G. J. Hankey, H. C. Harewood, R. Havmoeller, S. Hay, L. Hernandez, A. Husseini, B. T. Idrisov, N. Ikeda, F. Islami, E. Jahangir, S. K. Jassal, S. H. Jee, M. Jeffreys, J. B. Jonas, E. K. Kabagambe, S. E. A. H. Khalifa, A. P. Kengne, Y. S. Khader, Y.-H. Khang, D. Kim, R. W. Kimokoti, J. M. Kinge, Y. Kokubo, S. Kosen, G. Kwan, T. Lai, M. Leinsalu, Y. Li, X. Liang, S. Liu, G. Logroscino, P. A. Lotufo, Y. Lu, J. Ma, N. K. Mainoo, G. A. Mensah, T. R. Merriman, A. H. Mokdad, J. Moschandreas, M. Naghavi, A. Naheed, D. Nand, K. M. V. Narayan, E. L. Nelson, M. L. Neuhouser, M. I. Nisar, T. Ohkubo, S. O. Oti, A. Pedroza, D. Prabhakaran, N. Roy, U. Sampson, H. Seo, S. G. Sepanlou, K. Shibuya, R. Shiri, I. Shiue, G. M. Singh, J. A. Singh, V. Skirbekk, N. J. C. Stapelberg, L. Sturua, B. L. Sykes, M. Tobias, B. X. Tran, L. Trasande, H. Toyoshima, S. van de Vijver, T. J. Vasankari, J. L. Veerman, G. Velasquez-Melendez, V. V. Vlassov, S. E. Vollset, T. Vos, C. Wang, S. X. Wang, E. Weiderpass, A. Werdecker, J. L. Wright, Y. C. Yang, H. Yatsuya, J. Yoon, S.-J. Yoon, Y. Zhao, M. Zhou, S. Zhu, A. D. Lopez, C. J. L. Murray and E. Gakidou, Lancet, 2014, 384, 766781.

5 W. P. T. James, J. Int. Med., 2008, 263, 336-352.

6 L. O. Pereira-Lancha, D. F. Coelho, P. L. de Campos-Ferraz and A. H. Lancha, J. Am. Coll. Nutr., 2010, 29, 343-351.

7 J. P. Flatt, E. Ravussin, K. J. Acheson and E. Jéquier, J. Clin. Invest., 1985, 76, 1019-1024.

8 J. P. Flatt, Am. J. Clin. Nutr., 1987, 45, 296-306.

9 J. P. Flatt, Ann. N. Y. Acad. Sci., 1987, 499, 104-123.

10 A. Astrup, Obes. Rev., 2011, 12, 859-865.

11 M. J. M. Munsters and W. H. M. Saris, Annu. Rev. Food Sci. Technol., 2014, 5, 39-51.

12 A. Astrup, M. Kristensen, N. T. Gregersen, A. Belza, J. K. Lorenzen, A. Due and T. M. Larsen, Ann. N. Y. Acad. Sci., 2010, 1190, 25-41.

13 M. González-Castejón and A. Rodriguez-Casado, Pharmacol. Res., 2011, 64, 438-455.

14 M. Meydani and S. T. Hasan, Nutrients, 2010, 2, 737-751.

15 L. Trigueros, S. Peña, a. V. Ugidos, E. Sayas-Barberá, J. a. Pérez-Álvarez and E. Sendra, Crit. Rev. Food Sci. Nutr., 2013, 53, 929-942.

16 D. J. Williams, D. Edwards, I. Hamernig, L. Jian, A. P. James, S. K. Johnson and L. C. Tapsell, Food Res. Int., 2013, 52, 323-333.

17 J. K. Lin and S. Y. Lin-Shiau, Mol. Nutr. Food Res., 2006, 50, 211-217.

18 S. Wang, N. Moustaid-Moussa, L. Chen, H. Mo, A. Shastri, R. Su, P. Bapat, I. Kwun and C.-L. Shen, J. Nutr. Biochem., 2014, 25, 1-18.
19 T. Sergent, J. Vanderstraeten, J. Winand, P. Beguin and Y.-J. Schneider, Food Chem., 2012, 135, 68-73.

20 F. He, Q.-H. Pan, Y. Shi and C.-Q. Duan, Molecules, 2008, 13, 2674-2703.

21 A. Vogiatzoglou, A. a. Mulligan, R. N. Luben, M. a. H. Lentjes, C. Heiss, M. Kelm, M. W. Merx, J. P. E. Spencer, H. Schroeter and G. G. C. Kuhnle, Br. J. Nutr., 2014, 111, 1463-1473.

22 Y. Wang, S. Chung, W. O. Song and O. K. Chun, J. Nutr., 2011, 141, 447-452.

23 X. Terra, G. Montagut, M. Bustos, N. Llopiz, A. Ardèvol, C. Bladé, J. Fernández-Larrea, G. Pujadas, J. Salvadó, L. Arola and M. Blay, J. Nutr. Biochem., 2009, 20, 210-218.

24 H. Quesada, J. M. del Bas, D. Pajuelo, S. Díaz, J. Fernandez-Larrea, M. Pinent, L. Arola, M. J. Salvadó and C. Bladé, Int. J. Obes., 2009, 33, 1007-1012.

25 D. Del Rio, G. Borges and A. Crozier, Br. J. Nutr., 2010, 104 Suppl, S67-590.

26 L. Gu, M. A. Kelm, J. F. Hammerstone, G. Beecher, J. Holden, D. Haytowitz and R. L. Prior, J. Agric. Food Chem., 2003, 51, 7513-7521.

27 W. Hümmer and P. Schreier, Mol. Nutr. Food Res., 2008, 52, 1381-1398.

28 K. Ou and L. Gu, J. Funct. Foods, 2014, 7, 43-53.

29 S. Deprez, I. Mila, J. F. Huneau, D. Tome and A. Scalbert, Antioxid. Redox Signaling, 2001, 3, 957-967.

30 K. Ou, S. S. Percival, T. Zou, C. Khoo and L. Gu, J. Agric. Food Chem., 2012, 60, 1390-1396.

31 S. Rzeppa, K. Bittner, S. Döll, S. Dänicke and H.-U. Humpf, Mol. Nutr. Food Res., 2012, 56, 653-665.

32 T. Shoji, S. Masumoto, N. Moriichi, H. Akiyama, T. Kanda, Y. Ohtake and Y. Goda, J. Agric. Food Chem., 2006, 54, 884892.

33 A. Serra, A. Macià, M.-P. Romero, M.-J. Salvadó, M. Bustos, J. Fernández-Larrea and M.-J. Motilva, J. Chromatogr., B: Anal. Technol. Biomed. Life Sci., 2009, 877, 1169-1176.

34 S. P. Shrestha, J. a. Thompson, M. F. Wempe, M. Gu, R. Agarwal and C. Agarwal, Pharm. Res., 2012, 29, 856865.

35 S. Baba, N. Osakabe, M. Natsume and J. Terao, Free Radicals Biol. Med., 2002, 33, 142-148.

36 C. Tsang, C. Auger, W. Mullen, A. Bornet, J.-M. Rouanet, A. Crozier and P.-L. Teissedre, Br. J. Nutr., 2005, 94, 170181.

37 J. K. Prasain, N. Peng, Y. Dai, R. Moore, A. Arabshahi, L. Wilson, S. Barnes, J. Michael Wyss, H. Kim and R. L. Watts, Phytomedicine, 2009, 16, 233-243.

38 A. Sano, J. Yamakoshi, S. Tokutake, K. Tobe, Y. Kubota and M. Kikuchi, Biosci., Biotechnol., Biochem., 2003, 67, 1140-1143.

39 R. R. Holt, S. A. Lazarus, M. C. Sullards, Q. Y. Zhu, D. D. Schramm, J. F. Hammerstone, C. G. Fraga, H. H. Schmitz and C. L. Keen, Am. J. Clin. Nutr., 2002, 76, 798-804.

40 M. Urpi-Sarda, M. Monagas, N. Khan, R. M. LamuelaRaventos, C. Santos-Buelga, E. Sacanella, M. Castell, 
J. Permanyer and C. Andres-Lacueva, Anal. Bioanal. Chem., 2009, 394, 1545-1556.

41 J. L. Donovan, C. Manach, L. Rios, C. Morand, A. Scalbert and C. Rémésy, Br. J. Nutr., 2002, 87, 299-306.

42 Y. Nakamura and Y. Tonogai, J. Agric. Food Chem., 2003, 51, 7215-7225.

43 A. Arola-Arnal, G. Oms-Oliu, A. Crescenti, J. M. del Bas, M. R. Ras, L. Arola and A. Caimari, Mol. Nutr. Food Res., 2013, 57, 1741-1752.

44 A. Serra, A. Macià, L. Rubió, N. Anglès, N. Ortega, J. R. Morelló, M.-P. Romero and M.-J. Motilva, Eur. J. Nutr., 2013, 52, 1029-1038.

45 A. Serra, A. Macià, M.-P. Romero, C. Piñol and M.-J. Motilva, J. Chromatogr., B: Anal. Technol. Biomed. Life Sci., 2011, 879, 1519-1528.

46 E. M. Janle, M. A. Lila, M. Grannan, L. Wood, R. B. Rogers, H. Kim, G. S. Jackson, L. Ho and C. M. Weaver, J. Med. Food, 2010, 13, 926-933.

47 J. P. Spencer, F. Chaudry, A. S. Pannala, S. K. Srai, E. Debnam and C. Rice-Evans, Biochem. Biophys. Res. Commun., 2000, 272, 236-241.

48 Q. Y. Zhu, R. R. Holt, S. a. Lazarus, J. L. Ensunsa, J. F. Hammerstone, H. H. Schmitz and C. L. Keen, J. Agric. Food Chem., 2002, 50, 1700-1705.

49 R. M. Hackman, J. a. Polagruto, Q. Y. Zhu, B. Sun, H. Fujii and C. L. Keen, Phytochem. Rev., 2007, 7, 195-208.

50 L. Y. Rios, R. N. Bennett, S. A. Lazarus, C. Remesy, A. Scalbert and G. Williamson, Am. J. Clin. Nutr., 2002, 76, 1106-1110.

51 J. I. Ottaviani, C. Kwik-Uribe, C. L. Keen and H. Schroeter, Am. J. Clin. Nutr., 2012, 95, 851-858.

52 A. Serra, A. Macià, M.-P. Romero, J. Valls, C. Bladé, L. Arola and M.-J. Motilva, Br. J. Nutr., 2010, 103, 944952.

53 L. Gu, S. E. House, L. Rooney and R. L. Prior, J. Agric. Food Chem., 2007, 55, 5326-5334.

54 M. Monagas, M. Urpi-Sarda, F. Sánchez-Patán, R. Llorach, I. Garrido, C. Gómez-Cordovés, C. Andres-Lacueva and B. Bartolomé, Food Funct., 2010, 1, 233-253.

55 S. V. Verstraeten, C. L. Keen, H. H. Schmitz, C. G. Fraga and P. I. Oteiza, Free Radicals Biol. Med., 2003, 34, 84-92.

56 S. V. Verstraeten, G. K. Jaggers, C. G. Fraga and P. I. Oteiza, Biochim. Biophys. Acta, 2013, 1828, 2646-2653.

57 K. M. Goodrich and A. P. Neilson, J. Chromatogr., B: Anal. Technol. Biomed. Life Sci., 2014, 958, 63-74.

58 Y. Y. Choy, G. K. Jaggers, P. I. Oteiza and A. L. Waterhouse, J. Agric. Food Chem., 2013, 61, 121-127.

59 C. Cueva, F. Sánchez-Patán, M. Monagas, G. E. Walton, G. R. Gibson, P. J. Martín-Álvarez, B. Bartolomé and M. V. Moreno-Arribas, FEMS Microbiol. Ecol., 2013, 83, 792-805.

60 R. Roig, E. Cascón, L. Arola, C. Bladé and M. J. Salvadó, Biochim. Biophys. Acta, 2002, 1572, 25-30.

61 N. Llópiz, F. Puiggròs, E. Céspedes, L. Arola, A. Ardévol, C. Bladé and M. J. Salvadó, J. Agric. Food Chem., 2004, 52, 1083-1087.
62 F. Puiggros, N. Llópiz, A. Ardévol, C. Bladé, L. Arola and M. J. Salvadó, J. Agric. Food Chem., 2005, 53, 6080-6086.

63 F. Puiggròs, E. Sala, M. Vaqué, A. Ardévol, M. Blay, J. Fernández-Larrea, L. Arola, C. Bladé, G. Pujadas and M. J. Salvadó, J. Agric. Food Chem., 2009, 57, 3934-3942.

64 Y. A. Lee, E. J. Cho, T. Tanaka and T. Yokozawa, J. Nutr. Sci. Vitaminol., 2007, 53, 287-292.

65 R. de la Iglesia, F. I. Milagro, J. Campión, N. Boqué and J. A. Martínez, BioFactors, 2010, 36, 159-168.

66 A. Caimari, J. M. del Bas, A. Crescenti and L. Arola, Int. J. Obes., 2013, 37, 576-583.

67 M. Vadillo, A. Ardévol, J. Fernández-Larrea, G. Pujadas, C. Bladé, M. J. Salvadó, L. Arola and M. Blay, J. Nutr. Biochem., 2006, 17, 139-142.

68 M. R. Dorenkott, L. E. Griffin, K. M. Goodrich, K. a. Thompson-Witrick, G. Fundaro, L. Ye, J. R. Stevens, M. Ali, S. F. O'Keefe, M. W. Hulver and A. P. Neilson, J. Agric. Food Chem., 2014, 62, 2216-2227.

69 N. Matsui, R. Ito, E. Nishimura, M. Yoshikawa, M. Kato, M. Kamei, H. Shibata, I. Matsumoto, K. Abe and S. Hashizume, Nutrition, 2005, 21, 594-601.

70 M. Yamamoto, S. Shimura, Y. Itoh, T. Ohsaka, M. Egawa and S. Inoue, Int. J. Obes. Relat. Metab. Disord., 2000, 24, 758-764.

71 H. Kimura, S. Ogawa, A. Sugiyama, M. Jisaka, T. Takeuchi and K. Yokota, Food Res. Int., 2011, 44, 121-126.

72 N. Ikarashi, T. Toda, T. Okaniwa, K. Ito, W. Ochiai and K. Sugiyama, J Evidence-Based. Complementary Altern. Med., 2011, 2011, 952031-952040.

73 X. Terra, V. Pallarés, A. Ardèvol, C. Bladé, J. FernándezLarrea, G. Pujadas, J. Salvadó, L. Arola and M. Blay, J. Nutr. Biochem., 2011, 22, 380-387.

74 D. Pajuelo, H. Quesada, S. Díaz, A. Fernández-Iglesias, A. Arola-Arnal, C. Bladé, J. Salvadó and L. Arola, Br. J. Nutr., 2012, 107, 170-178.

75 E. Casanova, L. Baselga-Escudero, A. Ribas-Latre, L. Cedó, A. Arola-Arnal, M. Pinent, C. Bladé, L. Arola and M. J. Salvadó, J. Nutr. Biochem., 2014, 25, 1003-1010.

76 V. M. Castrillejo, M.-M. Romero, M. Esteve, A. Ardévol, M. Blay, C. Bladé, L. Arola and M. J. Salvadó, Nutrition, 2011, 27, 1172-1176.

77 V. Pallarès, A. Fernández-Iglesias, L. Cedó, A. Castell-Auví, M. Pinent, A. Ardévol, M. J. Salvadó, S. Garcia-Vallvé and M. Blay, Free Radicals Biol. Med., 2013, 60, 107-114.

78 G. Montagut, C. Bladé, M. Blay, J. Fernández-Larrea, G. Pujadas, M. J. Salvadó, L. Arola, M. Pinent and A. Ardévol, J. Nutr. Biochem., 2010, 21, 961-967.

79 A. Agouni, A.-H. Lagrue-Lak-Hal, H. A. Mostefai, A. Tesse, P. Mulder, P. Rouet, F. Desmoulin, C. Heymes, M. C. Martínez and R. Andriantsitohaina, PLoS One, 2009, 4, e5557.

80 N. Osakabe, M. Yamagishi, M. Natsume, A. Yasuda and T. Osawa, Exp. Biol. Med., 2004, 229, 33-39.

81 M. Tomaru, H. Takano, N. Osakabe, A. Yasuda, K. Inoue, R. Yanagisawa, T. Ohwatari and H. Uematsu, Nutrition, 2007, 23, 351-355. 
82 B. A. Golomb, S. Koperski and H. L. White, Arch. Intern. Med., 2012, 172, 519-521.

83 R. B. Birari and K. K. Bhutani, Drug Discovery Today, 2007, 12, 879-889.

84 T. Horigome, R. Kumar and K. Okamoto, Br. J. Nutr., 1988, 60, 275-285.

85 C. Santos-Buelga and A. Scalbert, J. Sci. Food Agric., 2000, 80, 1094-1117.

86 J. Xiao, M. Suzuki, X. Jiang, X. Chen, K. Yamamoto, F. Ren and M. Xu, J. Agric. Food Chem., 2008, 56, 2350-2356.

87 T. Hatano, A. Yamashita, T. Hashimoto, H. Ito, N. Kubo, M. Yoshiyama, S. Shimura, Y. Itoh, T. Okuda and T. Yoshida, Phytochemistry, 1997, 46, 893-900.

88 H. Sugiyama, Y. Akazome, T. Shoji, A. Yamaguchi, M. Yasue, T. Kanda and Y. Ohtake, J. Agric. Food Chem., 2007, 55, 4604-4609.

89 R. Gonçalves, N. Mateus and V. de Freitas, J. Agric. Food Chem., 2010, 58, 11901-11906.

90 Y. Gu, W. J. Hurst, D. a. Stuart and J. D. Lambert, J. Agric. Food Chem., 2011, 59, 5305-5311.

91 K. Koga, M. Hisamura, T. Kanetaka, K. Yoshino, Y. Matsuo and T. Tanaka, J. Food Sci., 2013, 78, H105H111.

92 S. I. Koo and S. K. Noh, J. Nutr. Biochem., 2007, 18, 179183.

93 H. Kimura, S. Ogawa, T. Akihiro and K. Yokota, J. Chromatogr., A, 2011, 1218, 7704-7712.

94 R. Kusano, S. Ogawa, Y. Matsuo, T. Tanaka, Y. Yazaki and I. Kouno, J. Nat. Prod., 2011, 74, 119-128.

95 S. Pal, M. Naissides and J. Mamo, Int. J. Obes. Relat. Metab. Disord., 2004, 28, 324-326.

96 Y. Toyoda-Ono, M. Yoshimura, M. Nakai, Y. Fukui, S. Asami, H. Shibata, Y. Kiso and I. Ikeda, Biosci., Biotechnol., Biochem., 2007, 71, 971-976.

97 H. Wang, L. Song, S. Feng, Y. Liu, G. Zuo, F. Lai, G. He, M. Chen and D. Huang, Molecules, 2013, 18, 2255-2265.

98 H. Wang, T. Liu, L. Song and D. Huang, J. Agric. Food Chem., 2012, 60, 3098-3104.

99 A. S. Boath, D. Grussu, D. Stewart and G. J. McDougall, Food Dig., 2012, 3, 1-7.

100 K. Kawakami, S. Aketa, M. Nakanami, S. Iizuka and M. Hirayama, Biosci., Biotechnol., Biochem., 2010, 74, 1380-1385.

101 M. Monagas, C. Gómez-Cordovés, B. Bartolomé, O. Laureano and J. M. Ricardo da Silva, J. Agric. Food Chem., 2003, 51, 6475-6481.

102 S. Soares, N. Mateus and V. de Freitas, J. Agric. Food Chem., 2007, 55, 6726-6735.

103 T. Tsujita, T. Shintani and H. Sato, J. Agric. Food Chem., 2013, 61, 4570-4576.

104 M. Yilmazer-Musa, A. M. Griffith, A. J. Michels, E. Schneider and B. Frei, J. Agric. Food Chem., 2012, 60, 8924-8929.

105 A. Barrett, T. Ndou, C. A. Hughey, C. Straut, A. Howell, Z. Dai and G. Kaletunc, J. Agric. Food Chem., 2013, 61, 1477-1486.
106 G. Williamson, Mol. Nutr. Food Res., 2013, 57, 48-57.

107 S. Almoosawi, C. Tsang, L. M. Ostertag, L. Fyfe and E. A. S. Al-Dujaili, Food Funct., 2012, 3, 1035-1043.

108 N. F. Brás, R. Gonçalves, N. Mateus, P. a. Fernandes, M. J. Ramos and V. de Freitas, J. Agric. Food Chem., 2010, 58, 10668-10676.

109 R. Gonçalves, N. Mateus, I. Pianet, M. Laguerre and V. de Freitas, Langmuir, 2011, 27, 13122-13129.

110 M. Tanida, N. Tsuruoka, J. Shen, Y. Horii, Y. Beppu, Y. Kiso and K. Nagai, Biosci., Biotechnol., Biochem., 2009, 73, 2374-2378.

111 K. S. Panickar, Mol. Nutr. Food Res., 2013, 57, 34-47.

112 E. T. Massolt, P. M. van Haard, J. F. Rehfeld, E. F. Posthuma, E. van der Veer and D. H. Schweitzer, Regul. Pept., 2010, 161, 81-86.

113 M. Tschöp, D. L. Smiley and M. L. Heiman, Nature, 2000, 407, 908-913.

114 A. Castell-Auví, L. Cedó, V. Pallarès, M. Blay, A. Ardévol and M. Pinent, Br. J. Nutr., 2012, 108, 1155-1162.

115 M. Pinent, M. Blay, M. C. Bladé, M. J. Salvadó, L. Arola and A. Ardévol, Endocrinology, 2004, 145, 4985-4990.

116 A. Castell-Auví, L. Cedó, V. Pallarès, M. Blay, M. Pinent and A. Ardévol, J. Nutr. Biochem., 2013, 24, 948-953.

117 M. Pinent, M. C. Bladé, M. J. Salvadó, L. Arola and A. Ardévol, J. Agric. Food Chem., 2005, 53, 5932-5935.

118 L. Cedó, A. Castell-Auví, V. Pallarès, M. Blay, A. Ardévol, L. Arola and M. Pinent, Food Chem., 2013, 138, 524-530.

119 N. González-Abuín, N. Martínez-Micaelo, M. Blay, G. Pujadas, S. Garcia-Vallvé, M. Pinent and A. Ardévol, J. Agric. Food Chem., 2012, 60, 9055-9061.

120 Y. Yamashita, M. Okabe, M. Natsume and H. Ashida, Biosci., Biotechnol., Biochem., 2013, 77, 888-891.

121 N. González-Abuín, N. Martínez-Micaelo, M. Blay, A. Ardévol and M. Pinent, J. Agric. Food Chem., 2014, 62, 1066-1072.

122 M. Pinent, C. Bladé, M. J. Salvadó, M. Blay, G. Pujadas, J. Fernández-Larrea, L. Arola and A. Ardévol, Crit. Rev. Food Sci. Nutr., 2006, 46, 543-550.

123 J. Ogasawara, K. Kitadate, H. Nishioka, H. Fujii, T. Sakurai, T. Kizaki, T. Izawa, H. Ishida and H. Ohno, Phytother. Res., 2009, 23, 1626-1633.

124 M. Colitti and S. Grasso, Biofactors, 2014, 1-21.

125 M. Pinent, M. C. Bladé, M. J. Salvadó, L. Arola, H. Hackl, J. Quackenbush, Z. Trajanoski and A. Ardévol, Int. J. Obes., 2005, 29, 934-941.

126 M. E. Schreckinger, J. Wang, G. Yousef, M. A. Lila and E. Gonzalez de Mejia, J. Agric. Food Chem., 2010, 58, 89668976.

127 A. Frontini and S. Cinti, Cell Metab., 2010, 11, 253-256.

128 J. Wu, P. Boström, L. M. Sparks, L. Ye, J. H. Choi, A.-H. Giang, M. Khandekar, K. A. Virtanen, P. Nuutila, G. Schaart, K. Huang, H. Tu, W. D. van Marken Lichtenbelt, J. Hoeks, S. Enerbäck, P. Schrauwen and B. M. Spiegelman, Cell, 2012, 150, 366-376.

129 M. L. Bonet, P. Oliver and A. Palou, Biochim. Biophys. Acta, 2013, 1831, 969-985. 
130 M. Pinent, L. Cedó, G. Montagut, M. Blay and A. Ardévol, Crit. Rev. Food Sci. Nutr., 2012, 52, 569-584.

131 R. Zamora-Ros, N. G. Forouhi, S. J. Sharp, C. A. González, B. Buijsse, M. Guevara, Y. T. van der Schouw, P. Amiano, H. Boeing, L. Bredsdorff, G. Fagherazzi, E. J. Feskens, P. W. Franks, S. Grioni, V. Katzke, T. J. Key, K.-T. Khaw, T. Kühn, G. Masala, A. Mattiello, E. Molina-Montes, P. M. Nilsson, K. Overvad, F. Perquier, M. L. Redondo, F. Ricceri, O. Rolandsson, I. Romieu, N. Roswall, A. Scalbert, M. Schulze, N. Slimani, A. M. W. Spijkerman, A. Tjonneland, M. J. Tormo, M. Touillaud, R. Tumino, D. L. van der A, G. J. van Woudenbergh, C. Langenberg, E. Riboli and N. J. Wareham, J. Nutr., 2014, 144, 335-343.

132 P. F. Jacques, A. Cassidy, G. Rogers, J. J. Peterson, J. B. Meigs and J. T. Dwyer, J. Nutr., 2013, 143, 14741480.

133 X. Liu, J. Wei, F. Tan, S. Zhou, G. Würthwein and P. Rohdewald, Life Sci., 2004, 75, 2505-2513.

134 X. Liu, H.-J. Zhou and P. Rohdewald, Diabetes Care, 2004, 27, 839-839.

135 A. E. Banini, L. C. Boyd, J. C. Allen, H. G. Allen and D. L. Sauls, Nutrition, 2006, 22, 1137-1145.

136 P. J. Curtis, M. Sampson, J. Potter, K. Dhatariya, P. A. Kroon and A. Cassidy, Diabetes Care, 2012, 35, 226232.

137 C. H. Hsu, Y. L. Liao, S. C. Lin, T. H. Tsai, C. J. Huang and P. Chou, Altern. Med. Rev., 2011, 16, 157-163.

138 J. Balzer, T. Rassaf, C. Heiss, P. Kleinbongard, T. Lauer, M. Merx, N. Heussen, H. B. Gross, C. L. Keen, H. Schroeter and M. Kelm, J. Am. Coll. Cardiol., 2008, 51, 2141-2149.

139 D. D. Mellor, T. Sathyapalan, E. S. Kilpatrick, S. Beckett and S. L. Atkin, Diabetic Med., 2010, 27, 1318-1321.

140 A. A. Noemí González-Abuín, M. Pinent, À. CasanovaMartí, L. Arola and M. Blay, Curr. Med. Chem., 2015, 22, 39-50.

141 L. Cedó, A. Castell-Auví, V. Pallarès, M. Blay, A. Ardévol and M. Pinent, Int. J. Food Sci., 2013, 2013, 875314.

142 H. J. Zhang, B. P. Ji, G. Chen, F. Zhou, Y. C. Luo, H. Q. Yu, F. Y. Gao, Z. P. Zhang and H. Y. Li, J. Food Sci., 2009, 74, H1-H7.

143 P. Smirin, D. Taler, G. Abitbol, T. Brutman-Barazani, Z. Kerem, S. R. Sampson and T. Rosenzweig, J. Ethnopharmacol., 2010, 129, 10-17.

144 Z. Lu, Q. Jia, R. Wang, X. Wu, Y. Wu, C. Huang and Y. Li, Phytomedicine, 2011, 18, 298-302.

145 I. Cordero-Herrera, M. Á. Martín, L. Goya and S. Ramos, Food Chem. Toxicol., 2014, 64, 10-19.

146 Y. Kurimoto, Y. Shibayama, S. Inoue, M. Soga, M. Takikawa, C. Ito, F. Nanba, T. Yoshida, Y. Yamashita, H. Ashida and T. Tsuda, J. Agric. Food Chem., 2013, 61, 5558-5564.

147 I. Baiges, J. Palmfeldt, C. Bladé, N. Gregersen and L. Arola, Mol. Cell. Proteomics, 2010, 9, 1499-1513.

148 Y. Yamashita, M. Okabe, M. Natsume and H. Ashida, Arch. Biochem. Biophys., 2012, 527, 95-104.
149 G. Montagut, S. Onnockx, M. Vaqué, C. Bladé, M. Blay, J. Fernández-Larrea, G. Pujadas, M. J. Salvadó, L. Arola, I. Pirson, A. Ardévol and M. Pinent, J. Nutr. Biochem., 2010, 21, 476-481.

150 H. H. Lee, K. J. Kim, O. H. Lee and B. Y. Lee, Phyther. Res., 2010, 24, 1242-1249.

151 P. L. Huang, C. W. Chi and T. Y. Liu, Food Chem. Toxicol., 2013, 55, 137-143.

152 R. Sundaram, R. Naresh, P. Shanthi and P. Sachdanandam, Phytomedicine, 2013, 20, 577-584.

153 G. R. Gandhi, S. Ignacimuthu and M. G. Paulraj, Food Chem. Toxicol., 2011, 49, 2725-2733.

154 H. H. H. Feringa, D. A. Laskey, J. E. Dickson and C. I. Coleman, J. Am. Diet. Assoc., 2011, 111, 1173-1181.

155 S. M. Razavi, S. Gholamin, A. Eskandari, N. Mohsenian, A. Ghorbanihaghjo, A. Delazar, N. Rashtchizadeh, M. Keshtkar-Jahromi and H. Argani, J. Med. Food, 2013, 16, 255-258.

156 C. Bladé, L. Arola and M.-J. Salvadó, Mol. Nutr. Food Res., 2010, 54, 37-59.

157 J. M. Del Bas, J. Fernández-Larrea, M. Blay, A. Ardèvol, M. J. Salvadó, L. Arola and C. Bladé, FASEB J., 2005, 19, 479-481.

158 H. Quesada, S. Díaz, D. Pajuelo, A. Fernández-Iglesias, S. Garcia-Vallvé, G. Pujadas, M. J. Salvadó, L. Arola and C. Bladé, Br. J. Nutr., 2012, 108, 208-217.

159 L. Baselga-Escudero, A. Arola-Arnal, A. Pascual-Serrano, A. Ribas-Latre, E. Casanova, M.-J. Salvadó, L. Arola and C. Blade, PLoS One, 2013, 8, e69817.

160 Z. Pons, L. Guerrero, M. Margalef, L. Arola, A. Arola-Arnal and B. Muguerza, J. Physiol. Biochem., 2014, 70, 629-637.

161 H. Quesada, D. Pajuelo, a. Fernández-Iglesias, S. Díaz, a. Ardevol, M. Blay, M. J. Salvadó, L. Arola and C. Blade, Food Chem., 2011, 129, 1490-1494.

162 K. Tebib, P. Besançon and J. M. Rouanet, J. Nutr., 1994, 124, 2451-2457.

163 D. Moreno, N. Ilic, A. Poulev, D. L. Brasaemle, S. K. Fried and I. Raskin, Nutrition, 2003, 19, 876-879.

164 J. M. Del Bas, M. L. Ricketts, I. Baiges, H. Quesada, A. Ardevol, M. J. Salvadó, G. Pujadas, M. Blay, L. Arola, C. Bladé, D. D. Moore and J. Fernandez-Larrea, Mol. Nutr. Food Res., 2008, 52, 1172-1181.

165 J. M. Del Bas, M.-L. Ricketts, M. Vaqué, E. Sala, H. Quesada, A. Ardevol, M. J. Salvadó, M. Blay, L. Arola,

D. D. Moore, G. Pujadas, J. Fernandez-Larrea and

C. Bladé, Mol. Nutr. Food Res., 2009, 53, 805-814.

166 C. Bladé, L. Baselga-Escudero, M. J. Salvadó and A. ArolaArnal, Mol. Nutr. Food Res., 2013, 57, 58-70.

167 A. Arola-Arnal and C. Bladé, PLoS One, 2011, 6, e25982.

168 L. Baselga-Escudero, C. Bladé, A. Ribas-Latre, E. Casanova, M. J. Salvadó, L. Arola and A. Arola-Arnal, Mol. Nutr. Food Res., 2012, 56, 1636-1646.

169 J. Kopecky, G. Clarke, S. Enerbäck, B. Spiegelman and L. P. Kozak, J. Clin. Invest., 1995, 96, 2914-2923.

170 K. I. Stanford, R. J. W. Middelbeek, K. L. Townsend, D. An, E. B. Nygaard, K. M. Hitchcox, K. R. Markan, 
K. Nakano, M. F. Hirshman, Y.-H. Tseng and L. J. Goodyear, J. Clin. Invest., 2013, 123, 215-223.

171 D. Pajuelo, S. Díaz, H. Quesada, A. Fernández-Iglesias, M. Mulero, A. Arola-Arnal, M. J. Salvadó, C. Bladé and L. Arola, J. Agric. Food Chem., 2011, 59, 4279-4287.

172 A. G. Dulloo, Obes. Rev., 2011, 12, 866-883.

173 Y. Kanamoto, Y. Yamashita, F. Nanba, T. Yoshida, T. Tsuda, I. Fukuda, S. Nakamura-Tsuruta and H. Ashida, J. Agric. Food Chem., 2011, 59, 8985-8993.

174 T. Shimada, D. Tokuhara, M. Tsubata, T. Kamiya, M. Kamiya-Sameshima, R. Nagamine, K. Takagaki, Y. Sai, K.-I. Miyamoto and M. Aburada, Eur. J. Pharmacol., 2012, 677, 147-153.

175 J. C. E. Serrano, H. Gonzalo-Benito, M. Jové, S. Fourcade, A. Cassanyé, J. Boada, M. A. Delgado, A. E. Espinel, R. Pamplona and M. Portero-Otín, Mol. Nutr. Food Res., 2013, 57, 459-470.

176 N. Watanabe, K. Inagawa, M. Shibata and N. Osakabe, Lipids Health Dis., 2014, 13, 64.

177 T. Tanaka, J. Yamamoto, S. Iwasaki, H. Asaba, H. Hamura, Y. Ikeda, M. Watanabe, K. Magoori, R. X. Ioka, K. Tachibana, Y. Watanabe, Y. Uchiyama, K. Sumi, H. Iguchi, S. Ito, T. Doi, T. Hamakubo, M. Naito, J. Auwerx, M. Yanagisawa, T. Kodama and J. Sakai, Proc. Natl. Acad. Sci. U. S. A., 2003, 100, 15924-15929.

178 F. Villarroya, R. Iglesias and M. Giralt, PPAR Res., 2007, 2007, 74364 .

179 Y. Ohta, M. Sami, T. Kanda, K. Saito, K. Osada and H. Kato, J. Oleo Sci., 2006, 55, 305-314.

180 J. K. Kim, J. J. Fillmore, Y. Chen, C. Yu, I. K. Moore, M. Pypaert, E. P. Lutz, Y. Kako, W. Velez-Carrasco, I. J. Goldberg, J. L. Breslow and G. I. Shulman, Proc. Natl. Acad. Sci. U. S. A., 2001, 98, 7522-7527.

181 E. Casanova, L. Baselga-Escudero, A. Ribas-Latre, A. ArolaArnal, C. Bladé, L. Arola and M. J. Salvadó, BioFactors, 2014, 40, 146-156.
182 A. Yadav, M. A. Kataria, V. Saini and A. Yadav, Clin. Chim. Acta, 2013, 417, 80-84.

183 D. Pajuelo, A. Fernandez-Iglesias, S. Diaz, H. Quesada, A. Arola-Arnal, C. Blade, J. Salvado and L. Arola, J. Agric. Food Chem., 2011, 59, 8491-8498.

184 K. Decorde, P. L. Teissedre, T. Sutra, E. Ventura, J. P. Cristol and J. M. Rouanet, Mol. Nutr. Food Res., 2009, 53, 659-666.

185 N. Vogels, I. M. T. Nijs and M. S. Westerterp-Plantenga, Eur. J. Clin. Nutr., 2004, 58, 667-673.

186 M. Flechtner-Mors, H. K. Biesalski, C. P. Jenkinson, G. Adler and H. H. Ditschuneit, Int. J. Obes. Relat. Metab. Disord., 2004, 28, 1420-1426.

187 N. Ikarashi, R. Takeda, K. Ito, W. Ochiai and K. Sugiyama, Evidence-Based. Complementary Altern. Med., 2011, 2011, 272075.

188 A. E. K. Loo and D. Huang, J. Agric. Food Chem., 2007, 55, 9805-9810.

189 A. Schäfer and P. Högger, Diabetes Res. Clin. Pract., 2007, 77, 41-46.

190 J. L. Hargrove, P. Greenspan, D. K. Hartle and C. Dowd, J. Med. Food, 2011, 14, 799-807.

191 H. Zhang, Y. Yang and C. Ma, J. Agric. Food Chem., 2013, 61, 8814-8820.

192 R. Gonçalves, N. Mateus and V. de Freitas, J. Agric. Food Chem., 2010, 58, 11924-11931.

193 M. Pinent, M. C. Bladé, M. J. Salvadó, L. Arola and A. Ardévol, J. Agric. Food Chem., 2005, 53, 262266.

194 L. Cedó, A. Castell-Auví, V. Pallarès, C. Ubaida Mohien, I. Baiges, M. Blay, A. Ardévol and M. Pinent, Food Chem., 2012, 135, 1948-1956.

195 A. Castell-Auví, L. Cedó, J. Movassat, B. Portha, F. Sánchez-Cabo, V. Pallarès, M. Blay, M. Pinent and A. Ardévol, J. Agric. Food Chem., 2013, 61, 355363. 